\title{
Do Citizens Care About Government Debt? Evidence from Survey Experiments on Budgetary Priorities*
}

\author{
Björn Bremer ${ }^{\dagger} \quad$ Reto Bürgisser ${ }^{\ddagger}$
}

December 2021

Forthcoming in the European Journal of Political Research

\begin{abstract}
Ever since the Great Recession, public debt has become politicized. Some research suggests that citizens are fiscally conservative, while other research shows that they punish governments for implementing fiscal consolidation. This begs the question of whether and how much citizens care about debt. We argue that debt is not a priority for citizens because reducing it involves spending and tax trade-offs. Using a split-sample experiment and a conjoint experiment in four European countries, we show that fiscal consolidation at the cost of spending cuts or taxes hikes is less popular than commonly assumed. Revenue-based consolidation is especially unpopular, but expenditure-based consolidation is also contested. Moreover, the public has clear fiscal policy priorities: People do not favor lower debt and taxes, but they support higher progressive taxes to pay for more government spending. The paper furthers our understanding of public opinion on fiscal policies and the likely political consequences of austerity.
\end{abstract}

Keywords: Fiscal policies; government debt; austerity; trade-offs; public opinion; survey experiments; conjoint surveys

*The authors gratefully acknowledge funding from the ERC Project "Political Conflict in Europe in the Shadow of the Great Recession" (Project ID: 338875). This research design has been approved by the Ethics Committee of the European University Institute, Florence. Previous versions of this paper were presented at the annual conference of the Midwest Political Science Association, 2018, the International Meeting on Experimental and Behavioral Social Sciences, 2018; the general conference of the European Consortium of Political Research, 2018; the SwissGerman-Austrian Dreiländertagung, 2019, the annual conference of the Council of European Studies, 2019, and the annual meeting of the American Political Science Association, 2019. The paper was also presented at seminars at the European University Institute, the University of Bern, and the Max Planck Institute for the Study of Societies. We are very grateful for insightful comments and feedback from Despina Alexiadou, Klaus Armingeon, Lucio Baccaro, Dorothee Bohle, Charlotte Cavaille, Julian Erhardt, Lukas Haffert, Evelyne Hübscher, Hanspeter Kriesi, Erik Neimanns, Jonas Pontusson, and Line Rennwald. Three anonymous reviewers and the editors of the EJPR further helped to improve the manuscript. The usual disclaimers apply.

${ }^{\dagger}$ Max Planck Institute for the Study of Societies, Cologne. E-mail: bremer@mpifg.de

¥University of Zurich, Institute of Political Sciences. E-mail: buergisser@ipz.uzh.ch 


\section{Introduction}

In many advanced economies, government debt has steadily increased since the 1970s and the issue has become particularly salient and politicized since the Great Recession. Commencing with the Greek sovereign debt crisis, governments across Europe implemented fiscal consolidation. Under the guise of austerity, they slashed government spending and increased taxes to reduce government debt 11 In the absence of a viable "growth model" Baccaro and Pontusson, 2016), this contributed to a sluggish economic recovery across Europe (Blyth, 2013). It dampened demand, undermined state capacities in crucial areas such as healthcare or education, and resulted in considerable political turmoil (Copelovitch et al., 2016).

While macroeconomic policies were long considered part of the technocratic realm of "quiet politics" (Culpepper, 2011), they have moved into the electoral realm of "noisy politics" over the last decade. The cumulative impact of the financial crisis, the eurozone crisis, and the pandemic on Europe's economies has been unprecedented. Public debt has substantially increased, and the politicization of public debt and fiscal consolidation will likely accelerate yet again, once shortterm emergency measures to combat the fallout from the COVID-19 pandemic are over. Thus, governments will be confronted with tough fiscal policy choices, further exacerbating political conflict over fiscal policies.

In this context, it is vital to understand the citizens' fiscal policy preferences. To what extent do they care about debt? A large body of research finds that government debt is unpopular and fiscal consolidation is broadly in line with public opinion. According to this view, citizens are fiscal conservatives, who dislike government debt and support balanced budgets (e.g., Alesina et al., 2019; Arias and Stasavage, 2019; Bansak et al., 2021; Barnes and Hicks, 2018, 2021b; Giger and Nelson, 2011; Brender and Drazen, 2008; Peltzman, 1992). In contrast, other research suggests that citizens punish governments for implementing fiscal consolidation. According to this view, voters oppose spending cuts and tax increases, which reduce the popularity of governments, harm the re-election chances of incumbents, and contribute to the success of populist

\footnotetext{
${ }^{1}$ We define austerity as fiscal consolidation (i.e., the attempt to reduce the government's budget deficit) during hard economic times when an economy is below its potential. Austerity thus includes both revenue- and expenditure-based consolidation.
} 
parties (Bojar et al., 2021; Fetzer, 2019; Galofré-Vilà et al., 2021; Hübscher and Sattler, 2017, Hübscher et al. 2021; Jacques and Haffert, 2021; Talving, 2017). The debate about whether voters are fiscal conservatives is thus ongoing. For example, Bansak et al. (2021, p. 488) recently argued that "austerity ... is actually a popular response to economic crises among the voting public", while Hübscher et al. (2021, p. 1759) argued that "a large share of voters systematically objects to fiscal consolidation."

We weigh in on this debate by explicitly studying how much people care about government debt in the face of trade-offs. Trade-offs are ubiquitous in fiscal policy. Governments have to raise taxes or issue debt in exchange for government spending $2^{2}$ Citizens, however, seem to have conflicting preferences: They support higher government spending and lower taxes and thus want 'something for nothing' (Sears and Citrin, 1982) or 'more for less' (Welch, 1985). In the words of the former German finance minister Wolfgang Schäuble: "The sum of the wishes is greater than the amount of money available. Always. The majority of people want more government services, fewer taxes, and no debt. That cannot be achieved at the same time. ${ }^{3}$

In this paper, we shift from studying citizens' policy positions towards studying their policy priorities. We argue that unidimensional survey questions (e.g., should the government reduce the level of debt?) only capture citizens' unconstrained position net of their importance. However, priorities issue from both position and importance and are pivotal in times of tight budget constraints. To measure fiscal priorities we use data from two separate survey experiments conducted in four European countries (Germany, Italy, Spain, and the United Kingdom). Unlike previous studies, we directly measure the importance that people attach to government debt in two ways. First, we use a split-sample experiment which alludes respondents to the trade-offs associated with reducing government debt: lower spending or higher taxes. Second, we use a

${ }^{2}$ According to Keynesian economic theory, governments can decrease debt by raising spending or cutting taxes if the fiscal multiplier is positive and higher than one. However, this would still increase debt in the short-run because there is usually a time lag associated with fiscal policies. Immediate fiscal consolidation, therefore, involves tough choices.

${ }^{3}$ Own translation, original: "Die Summe der Wünsche ist größer als der Betrag an Geld, das da ist. Immer. Die Mehrheit der Menschen will mehr staatliche Leistungen, weniger Steuern und keine Schulden. Das lässt sich gleichzeitig gar nicht erreichen." (Source: Interview with Focus, 24 November 2014, http://www.wolfgang-schaeuble.de/ die-schwarze-null-steht-fuer-verlaesslichkeit/). 
conjoint experiment to measure multidimensional budgetary priorities towards different fiscal policies that are subject to a budget constraint.

While other studies have used conjoint experiments to study the most or least popular composition of austerity packages (tax increases and spending cuts), they do not include debt as a separate attribute and thereby implicitly assume that debt levels are fixed (Bansak et al., 2021, Hübscher et al., 2021). In contrast, we include debt as a separate attribute, which allows us to explicitly study the relative priority that citizens attribute to public debt compared to other fiscal policies. Most importantly, our approach makes budgetary trade-offs binding and avoids "free lunches" while still measuring citizens' preferences over expansion or retrenchment. It allows us to study people's relative priorities across fiscal policies in the face of multidimensional trade-offs. Therefore, we test whether citizens are willing to decrease government spending or raise taxes to achieve fiscal consolidation.

The results are twofold. First, the split-sample experiment shows that average support for fiscal consolidation is high in an unconstrained setting but plummets when respondents are informed about the associated fiscal trade-offs. Revenue-based consolidation is wildly unpopular, but expenditure-based consolidation is also contested. Second, our conjoint survey experiment reveals that fiscal consolidation is not a priority for citizens. The average citizen cares little about government debt compared to government spending and taxation. Although general tax increases are unpopular, respondents support a more progressive tax system to pay for additional government spending. Thus, studies based on unidimensional questions overstate citizens' support for austerity and how much they care about public debt, while they underestimate the support for progressive taxes. Moreover, fiscal priorities vary across socioeconomic groups and countries.

Overall, the paper makes several contributions. Substantively, we study public priorities towards the core elements of government budgets (spending, taxation, and borrowing) holistically, which resolves the long-standing puzzle that public opinion towards fiscal policies is inconsistent. We demonstrate that public debt is not a priority. By committing themselves to austerity, governments prioritized an aim - lowering debt - that the public cares very little about. By refraining from increasing top income taxes, they shied away from popular policies. This mismatch helps to make sense of some of the political turmoil that we observed in Europe in the 
wake of the Great Recession (Bremer et al. 2020): as mainstream parties adopted austerity, voters turned to alternatives on the far left and far right of the political spectrum (Bojar et al. 2021; Fetzer, 2019, Hübscher et al., 2021; Jacques and Haffert, 2021; Talving, 2017).

Methodologically, we build on an emerging field of research (e.g., Armingeon and Bürgisser 2021; Bremer and Bürgisser, 2021; Busemeyer and Garritzmann, 2017; Cavaille et al., 2020, Häusermann et al., 2019: Häusermann et al., 2021) to show that traditional, unidimensional survey questions consistently overstate support for individual fiscal policies. They do not allow inferences about respondents' fiscal policy priorities. Knowing citizens' priorities is crucial, however, because it helps scholars and policymakers to assess what citizens want if they cannot have their cake and eat it too. It also helps to better understand electoral competition and anticipate the likely consequences of different policies (see also Hanretty et al., 2020). To study priorities, we need to use survey instruments that more realistically capture the trade-offs that governments face. We use two different survey instruments, suggesting a novel way to conduct and analyze conjoint experiments that makes budgetary constraints binding.

To make these arguments, we first briefly review the literature on fiscal policy preferences and explain the paper's motivation. Second, we develop theoretical expectations about how citizens prioritize different fiscal policies when confronted with trade-offs. Then, we explain the research design in detail before discussing the results from both experiments. The final section concludes with a discussion of the broader implications.

\section{Government debt and public opinion: Do citizens have inconsis- tent preferences?}

In the 1970s, the literature on political business cycles argued that politicians are interested in using macroeconomic policies (including deficit-spending) to engineer a boom before elections (Nordhaus, 1975). It was believed that citizens support expansionary policies that increase debt, including higher government spending and lower taxation, due to self-interest. Nevertheless, empirical research showed that political business cycles hardly exist (Golden and Poterba, 1980) and that citizens have conservative fiscal attitudes, opposing large fiscal deficits (e.g., Blinder and Holtz-Eakin, 1984, Peltzman, 1992). Attitudes towards austerity vary over time (Barnes and 
Hicks, 2021a), but there is a lot of evidence that people are, on average, averse to government debt (Bansak et al., 2021; Barnes and Hicks, 2021b). They favor balanced budgets (Stix, 2013) and fiscal rules (Hayo and Neumeier, 2016), partly because elite cues and media framing make austerity popular (Barnes and Hicks, 2018; Bisgaard and Slothuus, 2018).

Further research even claims that voters support governments' efforts to reduce the public deficit and debt Alesina et al. 2019; Arias and Stasavage, 2019; Brender and Drazen, 2008, Giger and Nelson, 2011; Kalbhenn and Stracca, 2020). Most prominently, Alesina and his coauthors argued that 'there is no evidence of a systematic electoral penalty or fall in popularity for governments that follow restrained fiscal policies' (1998, p. 198). This supplements the influential "expansionary fiscal contraction" thesis: not only can fiscal consolidation have an expansionary economic effect, but voters do not punish such consolidation initiatives, either (also see Alesina et al., 2019).

However, the finding that citizens are fiscal conservatives cannot easily be squared with other research. First, there is a large amount of empirical evidence that government spending in general, and the welfare state in particular, enjoy widespread support among the public (Svallfors, 1997; Bremer and Bürgisser, 2021). This omnipresent support for the welfare state also explains why full-frontal attacks on major welfare state programs are difficult (e.g., Brooks and Manza, 2007; Pierson, 1996). Second, other research suggests that the same is true for lower taxes. Although modal respondents may prefer more progressive taxes, they generally support a lower level of taxes (Ballard-Rosa et al., 2017; Barnes, 2015).

Taken together, these findings are puzzling: while citizens support higher levels of government spending, they do not want to pay for it through tax increases or debt. As a result, academics have identified inconsistent preferences and a lack of congruence in people's thinking about fiscal programs for a long time (Mueller, 1963; Citrin, 1979; Sears and Citrin, 1982, Welch, 1985). As Wolfgang Schäuble recognized, this creates a dilemma for politicians and political parties, who have to square the circle when designing government budgets. As Bell 1976, p. 226-7) already contended: 'how much the government shall spend, and for whom, obviously is the major political question of the next decades ... [but] the pressure to increase services is not necessarily matched by the mechanisms to pay for them, either a rising debt or rising taxes.' 
Yet, public opinion research on fiscal policies tends to assess public opinion on individual policies independent of other fiscal policies. It does not capture the multidimensionality of fiscal policies and ignores that governments face difficult trade-offs (Adolph et al., 2020). In challenging economic times, governments cannot rely on growth to shrink the debt burden. Instead, they have to cut spending or increase taxes. Fiscal consolidation thus carries substantial trade-offs, which are not accounted for in unidimensional survey questions. To measure support for fiscal consolidation we need to directly measure whether voters care about government debt, which is something that even recent, sophisticated studies on fiscal policy preferences do not address. They either exclude debt from the analysis altogether (Barnes et al., 2021) or only measure support for features of austerity packages that do not include debt as a separate dimension (Bansak et al., 2021; Hübscher et al., 2021). Since governments cannot make decisions about debt in isolation from other policies, this does not adequately represent public budgeting and likely overstates public support for fiscal consolidation.

To measure whether voters support fiscal consolidation, we need to move beyond assessing people's position towards individual fiscal policies and move towards explicitly studying people's fiscal policy priorities in multidimensional choice settings. Knowing about people's priorities is important for several reasons (see also Hanretty et al., 2020). First, relying on unidimensional position questions to assess what the public wants is not helpful for policymakers. The resulting signals are incoherent since citizens support higher spending, lower taxes, and lower debt at the same time. In contrast, studying priorities will provide valuable information to policymakers and scholars alike about which policies citizens deem essential. Second, it allows us to better understand political competition and predict the electoral consequences of different fiscal policies. Voters should only react to different fiscal policies if they also care about them. Third, it enables us to study elite responsiveness to public opinion more carefully. Governments may be equally responsive to all citizens' policy positions, but they could still give more weight to the priorities of high- than low-income people (Bartels, 2016). 


\section{Taking trade-offs seriously: From policy positions towards priori- ties}

\section{Average fiscal policy priorities}

We assume that most fiscal policies are highly visible and salient (Soss and Schram, 2007) and that the average citizen evaluates fiscal policies in light of their costs and benefits and their temporal proximity (Campbell, 2012$)$. On the one hand, citizens do a cost-benefit analysis of fiscal policies because they care about the benefits they receive from spending and the costs associated with taxation and public debt. On the other hand, citizens add an intertemporal component into their cost-benefit analysis and evaluate whether fiscal policies impact current or future costs and benefits.

In principle, support for lower government debt may be high among the public, but it should drop when citizens face the inherent trade-offs that fiscal consolidations imply (Hansen, 1998, Hockley and Harbour, 1983). Debt is an abstract concept, and its impact on citizens is less direct than taxes (which they pay regularly) or government spending on public benefits or services (which many receive/use continuously). Compared to other dimensions of fiscal policy, government debt carries little cost for citizens. Only when countries face a sovereign debt crisis, the costs of debt increase and citizens directly feel adverse economic consequences. In all other circumstances, government debt has little influence on the average citizen's income, and they should not strongly care about it.

According to the Ricardian equivalence theorem, public debt can be seen as a form of future taxation. However, we know from the literature on intertemporal trade-offs that citizens are myopic and have high discount rates (Jacobs, 2011). When people evaluate government policies, they give less weight to long-term consequences than those that emerge in the short-term. Thus, it is reasonable to assume that budgetary decisions that affect current costs and benefits have a larger impact on citizens' priorities than budgetary decisions affecting future costs and benefits. They should not care very much about public debt, especially when governments face low borrowing costs due to low interest rates (Blanchard, 2019). 
Instead, citizens should care more about government spending and taxation. Following Pierson (1996), we assume that existing forms of government spending create strong electoral constituencies reluctant to accept retrenchment. For example, pensions are the most popular form of social spending in advanced welfare states because many people are retired or expect to retire. Similarly, citizens should be reluctant to increase taxation, which reduces the disposable income of almost all citizens, especially consumption taxes (VAT) and income taxes. The costs and benefits that government spending and taxation have for the average citizen are higher and influence the current income.

We, therefore, expect that government debt is not a priority for the average citizen. Most people care more about protecting their benefits (from government spending) or reducing their costs (from taxation) than lowering government debt. By this, we do not mean to say that people do not care at all about public debt. They indeed seem to support fiscal consolidation when asked about it in isolation. Given the abstract nature of public debt and the uncertainty of how public debt impacts citizens' future costs, however, we assume that citizens prioritize lower taxation and higher government spending over lower public debt. On average, support for fiscal consolidation should, therefore, decline substantially when the necessary spending and tax trade-offs are explicitly acknowledged.

Furthermore, we assume that citizens react differently to expenditure- than revenue-based consolidation because taxes affect most citizens' disposable income more directly than government spending. A large share of public spending does not directly flow into people's pockets: infrastructure, education, or even healthcare spending influences the median voter's disposable income indirectly, and often only in the future. In contrast, tax increases affect the median voter's budget much more directly: They immediately experience a drop in their disposable income. People should care more about the costs from taxation than the benefits of government spending and, therefore, be more opposed to revenue-based consolidation than expenditure-based consolidation.

Yet, revenue- and expenditure-based consolidation can be pursued in different ways. On the expenditure side, we can distinguish between immediate, short-term consumption spending (e.g., public pensions) and investment spending (e.g., education). Unlike consumption spending, the benefits of most investment spending accrue in the future. While almost all citizens benefit 
from education and pensions at a certain point in their lives, some citizens do not use the full educational offer and leave after mandatory school. On the revenue side, we can distinguish between general income taxes and consumption taxes. Generally, these taxes are a cost and reduce the disposable income, but the specific tax design determines how much the average citizen is affected by them. The average citizen should be reluctant to pay proportionally higher income and consumption taxes in general but be more inclined to prioritize progressive taxation (e.g., top income taxes).

Overall, this implies the following fiscal policy priorities for the average citizen: taxation should be the highest priority, followed by government spending and then by government debt. Although citizens prefer reducing debt, this has a lower priority than reducing taxes and increasing government spending. More specifically, we expect that citizens attach a high priority to pension spending and top income taxes, a medium priority to general income taxes, consumption taxes, and education, and a low priority to government debt.

\section{Heterogeneous fiscal policy priorities}

We expect that different socioeconomic groups may have heterogeneous fiscal priorities. Until today, we know very little about what drives priorities, as opposed to positions, but below we will test this in an exploratory fashion. Specifically, we expect people's priorities to differ according to three dimensions: material self-interest, ideology, and institutional context.

First, material self-interest likely influences attitudes towards fiscal consolidation (e.g., Meltzer and Richard, 1981). Income is the best measure of self-interest, as income groups have different cost-benefit calculations. For example, low-income citizens are more likely to benefit from public transfers than high-income citizens, and they should thus be more opposed to expenditure-based consolidation than revenue-based consolidation. In contrast, citizens who do not receive public transfers react more strongly to tax increases. Their disposable income is more directly affected by changes in taxation. They should thus react more strongly to tax increases than spending cuts.

Moreover, ideology also shapes attitudes towards fiscal policies (e.g., Jacoby, 1994, Margalit, 2013). Beliefs provide people with information about how the economy works and allow them 
to assess policies based on principles such as fairness (Limberg, 2019). In general, it is often thought that the left cares less about rising public debt, favoring deficits (Cusack, 1999). Leftwing citizens support government services and benefits and should be more likely to oppose expenditure-based consolidation than voters from the right. Right-wing citizens are more likely to support small governments and free markets, favoring lower taxes. They should be more opposed to revenue-based consolidation than left-wing citizens.

Finally, we know that existing institutions and policies have feedback effects (Pierson, 1996 Campbell, 2012, Gingrich and Ansell, 2012), likely causing people's priorities to vary by institutional context. Thus, the legacy of previous policies affects the current economic environment and the perceived need for different economic policies. Most importantly, the existing level of public debt could affect fiscal priorities. Even though interest rates on government bonds are relatively low, making the need to reduce public debt relatively small, some countries do face higher borrowing costs: Governments with higher debt usually have to pay higher interest rates and are more likely to face sovereign debt crises. The costs of these crises are substantial, and we thus expect average support for fiscal consolidation to be higher in countries that recently experienced such crises. In these contexts, people are more aware of the costs of debt than elsewhere.

\section{Research design}

We use two separate survey experiments to overcome problems associated with conventional surveys while making modest cognitive demands upon respondents. First, we use a split-sample experiment to gauge individuals' priorities for spending- and revenue-based fiscal consolidation. Second, we use a conjoint survey experiment to elicit multidimensional budgetary priorities 4 In contrast to related research on austerity (Hübscher et al., 2021; Bansak et al., 2021), our research design includes debt as a separate dimension in the conjoint survey experiment, which can increase or decrease. We can thus explicitly test whether respondents care about government debt instead of implicitly assuming that they do.

\footnotetext{
${ }^{4}$ To avoid treatment effects, the split-sample experiment occurred after the conjoint experiment. Appendix A provides more information about the questionnaire and survey flow.
} 
In both experiments, we refrain from using specific levels to keep them cognitively simple and allow comparisons across countries. Our pretest with an opt-in sample from Prolific showed that respondents were cognitively overwhelmed by more complex survey experiments with specific levels and that they preferred a simpler design with more straightforward levels.5. We assume that people do not need to know a lot about government budgets to evaluate different alternatives (Sanders, 1988; Hansen, 1998). Governments decide on budgets annually, and budgetary debates are a regular feature of the political discourse familiar to many citizens. Thus, citizens only need to know the rough contours of a policy to decide whether they like it or not 6

\section{Part 1: Experiment with split-sample questions}

The first survey experiment explicitly tests how individuals change their priorities on fiscal consolidation when confronted with two-dimensional trade-offs. We randomly assigned respondents to three different groups, including one control group and two treatment groups 7 In each group, respondents evaluated a statement about government debt (see Table 1). We confronted respondents in the treatment groups with different statements that raised awareness of budgetary trade-offs: spending-based fiscal consolidation and revenue-based fiscal consolidation. The control group was presented with a statement that did not mention any trade-offs. Subsequently, respondents evaluated to what extent they agree or disagree with these different statements.

To analyze whether support for fiscal consolidation varies across the three groups, we graphically present the predicted mean support for fiscal consolidation for the control and the two treatment groups based on OLS regression. As a robustness test, we also control for several covariates (e.g., age, sex, marital status, education, income, employment status, union membership, and partisanship), and we add country-fixed effects (see Appendix A for the detailed operationalization of all variables). Moreover, we analyze heterogeneous effects by income, partisanship, and country.

\footnotetext{
${ }^{5} \mathrm{~A}$ drawback of not using more specific levels is that respondents may not perceive changes in different policies as equivalent.

${ }^{6}$ The research design was pre-registered and received ethical approval from the Ethics Committee of the European University Institute before the survey was fielded.

${ }^{7}$ The randomization resulted in well-balanced groups, as shown in Appendix A.
} 
Table 1: Design of the split-sample experiment

\begin{tabular}{l|l|l}
\hline Split & Treatment & Question \\
\hline 1 & Control group & $\begin{array}{l}\text { The government should reduce the level of government debt. } \\
\text { The government should reduce the level of government debt, } \\
\text { even if that implies lower government spending. } \\
\text { The government should reduce the level of government debt, } \\
\text { even if that implies higher taxes. }\end{array}$ \\
\hline
\end{tabular}

\section{Part 2: Conjoint survey experiment}

Before confronting respondents with the split-sample experiment introduced above, the survey included a conjoint survey experiment to study public priorities towards fiscal policies in a multidimensional setting. Conjoint survey experiments are useful for this purpose because respondents have to evaluate policy packages rather than individual policies (Hainmueller et al. 2014). Specifically, we asked respondents to evaluate changes to the government budget in a set of choice tasks. They were asked five times to choose (i) between two fiscal packages (choice variable) and (ii) how likely they are to support each of the packages (ranking variable). The profiles comprised six attributes corresponding to particular elements of a government budget (see Table 21), and each attribute could take on a set of discrete and predefined levels. Before asking respondents to evaluate the policy packages, we told them to consider the situation of their country, i.e., using their country's debt, spending, and tax levels as a reference point 8

The fiscal packages' attributes represent the three dimensions of government budgets: spending, taxation, and debt. To reduce complexity and avoid cognitive exhaustion, we limited the number of attributes and levels. Thus, we selected major spending and taxation items that directly influence citizens' disposable income. The profiles include two highly popular spending items, allowing us to distinguish social investment (education) and social consumption (pension). The profiles further distinguish between three different taxes: income tax, top income tax, and value-added tax. These attributes include direct and indirect taxes, they relate to the level of taxes (income tax, VAT) and the progressivity (top income tax), and they are among the politically most visible and salient forms of taxation. Finally, the profiles include debt as a separate

\footnotetext{
${ }^{8}$ The detailed conjoint instructions and an example are shown in Appendix D. The attribute order was randomized but held constant within respondents across the five tasks. Spending and taxation attributes were presented as a block.
} 
Table 2: Attributes and levels of the conjoint experiment

\begin{tabular}{|c|c|c|}
\hline & Attribute & Attribute levels \\
\hline \multirow{2}{*}{ 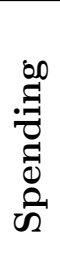 } & Old-age pensions & $\begin{array}{l}\text { Increase spending } \\
\text { No change } \\
\text { Decrease spending }\end{array}$ \\
\hline & Education & $\begin{array}{l}\text { Increase spending } \\
\text { No change } \\
\text { Decrease spending }\end{array}$ \\
\hline \multirow{3}{*}{ 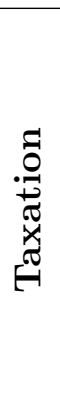 } & Income tax (for all citizens) & $\begin{array}{l}\text { Decrease } \\
\text { No change } \\
\text { Increase }\end{array}$ \\
\hline & Top income tax & $\begin{array}{l}\text { Decrease } \\
\text { No change } \\
\text { Increase }\end{array}$ \\
\hline & Value added tax (VAT) & $\begin{array}{l}\text { Decrease } \\
\text { No change } \\
\text { Increase }\end{array}$ \\
\hline$\frac{\overrightarrow{0}}{\ddot{0}}$ & Government debt & $\begin{array}{l}\text { Decrease } \\
\text { No change } \\
\text { Increase }\end{array}$ \\
\hline
\end{tabular}

dimension that allows governments to raise revenues. There are three levels (increase, decrease, no change) for each attribute, allowing us to test priorities towards different combinations of government spending, taxation, and debt.

In a fully randomized setting, there would be a total of 729 combinations. However, to represent the budgetary process accurately and to account for trade-offs, we introduced restrictions to avoid illogical combinations. In reality, taxes and government debt pay for government spending. To ensure external validity, we made budgetary constraints binding and only allowed combinations in which every increase in expenditure or decrease in revenues is matched by a simultaneous decrease in expenditure or increase in revenues. 588 combinations were thus excluded, leaving us with 141 possible combinations. However, the likelihood that a certain level appears together with another level is still the same because logical inconsistencies were uniformly deleted. This is due to the fact that each attribute has three symmetrical levels (increase, decrease, no change).

We calculate two main variables of interest from the conjoint experiment. First, we estimate the causal effect of individual attribute levels on the support for the entire fiscal package, compared to the baseline attribute level (status quo) (Hainmueller et al., 2014). The desirable property of the average marginal component effect (AMCE) is that it incorporates both the 
position and the importance that individuals assign to each attribute level (Bansak et al., 2020) and captures what we conceptually understand as policy priorities. Second, to analyze subgroup differences by income, partisanship, and country, we calculate the conditional marginal means for all attribute levels, which measure how favorable respondents are to a given feature of our fiscal packages (Leeper et al. 2020) 9

To estimate the AMCEs and marginal means, we use ridge regression. Standard conjoint experiments have dimensions that are independent and fully randomized. Budgetary trade-offs are not independent by design: changing expenditures or revenues on one attribute requires a change in another attribute. Our experimental design was informed by this target distribution of profiles about which we wanted to make inferences, namely realistic budgetary combinations. Each attribute value depends on the other attributes' values to ensure that the budget is fully balanced. To account for these dependencies, we suggest a novel approach using ridge regression Hoerl and Kennard (1970). Ridge regression is a standard regularization method that can be used to address design-based super-collinearity. Horiuchi et al. (2018) also used ridge regression for conjoint analysis. To estimate ridge regression, we use the $\mathrm{R}$ package glmnet, and we use bootstrapping to calculate non-parametric confidence intervals, which allows us to make inferences about the effect of a changing attribute value, averaging over the randomization distribution of our 141 profiles. The method and rationale are further explained in Appendix E

We used a series of tests to check the robustness of our conjoint results. We replicated our conjoint analyses using the rating variable instead of the choice variable (see Appendix F.3) and we conducted several standard robustness tests discussed in Appendix $\mathrm{H}$ (carryover effects, profile order effects, screen size, speeding, choice task round). They were designed to check that the standard assumptions of conjoint analysis are satisfied and to probe potential concerns about the validity of the results. The tests indicate that the results shown below are robust.

\footnotetext{
${ }^{9}$ Additional tests for heterogeneous effects did not reveal significant differences (see Appendix F.1.
} 


\section{Sample}

Both experiments were included in a survey that we fielded in 2018 in Germany, Italy, Spain, and the United Kingdom (UK). We selected the countries to test whether the overall priorities are similar across different contexts. They represent four major European economies characterized by different variants of capitalism (Hall and Soskice, 2001$)$ and growth models (Baccaro and Pontusson, 2016). Given the salience of macroeconomic policies and fiscal adjustment during the European sovereign debt crisis, we included two Southern European countries (Italy and Spain) in the survey along with Germany (a coordinated market economy) and the UK (a liberal market economy), which both had witnessed fiscal consolidation in post-crisis Europe 10

We recruited 1,200 eligible voters in each country from a large online panel provided by Qualtrics. By relying on quota sampling based on age and gender, our sample is representative of all eligible voters based on gender and age. The sample also closely corresponds to the general population in terms of income and partisanship (see Appendix B for the sampling strategy), except that center-right voters are slightly underrepresented in Germany and the United Kingdom. We further matched the population's demographic margins in each country as closely as possible using entropy balancing (Hainmueller, 2012). The results are presented in Appendix $\mathrm{G}$ and yield the same findings. Finally, to ensure our sample's overall quality, we included an attention check and speeding checks. It automatically screened out respondents who paid no attention or sped through the survey.

\section{Results}

\section{Average support for different types of fiscal consolidation}

To estimate the impact of the treatments and highlight the importance of budgetary trade-offs, the left panel of Figure 1 shows the mean support and 95 percent confidence intervals for fiscal consolidation in an unconstrained setting (control group) and the two different trade-off treatments. Our survey confirms the conventional finding that a vast majority of Europe's citizens

\footnotetext{
${ }^{10}$ For more information on case selection, see Appendix $B$.
} 

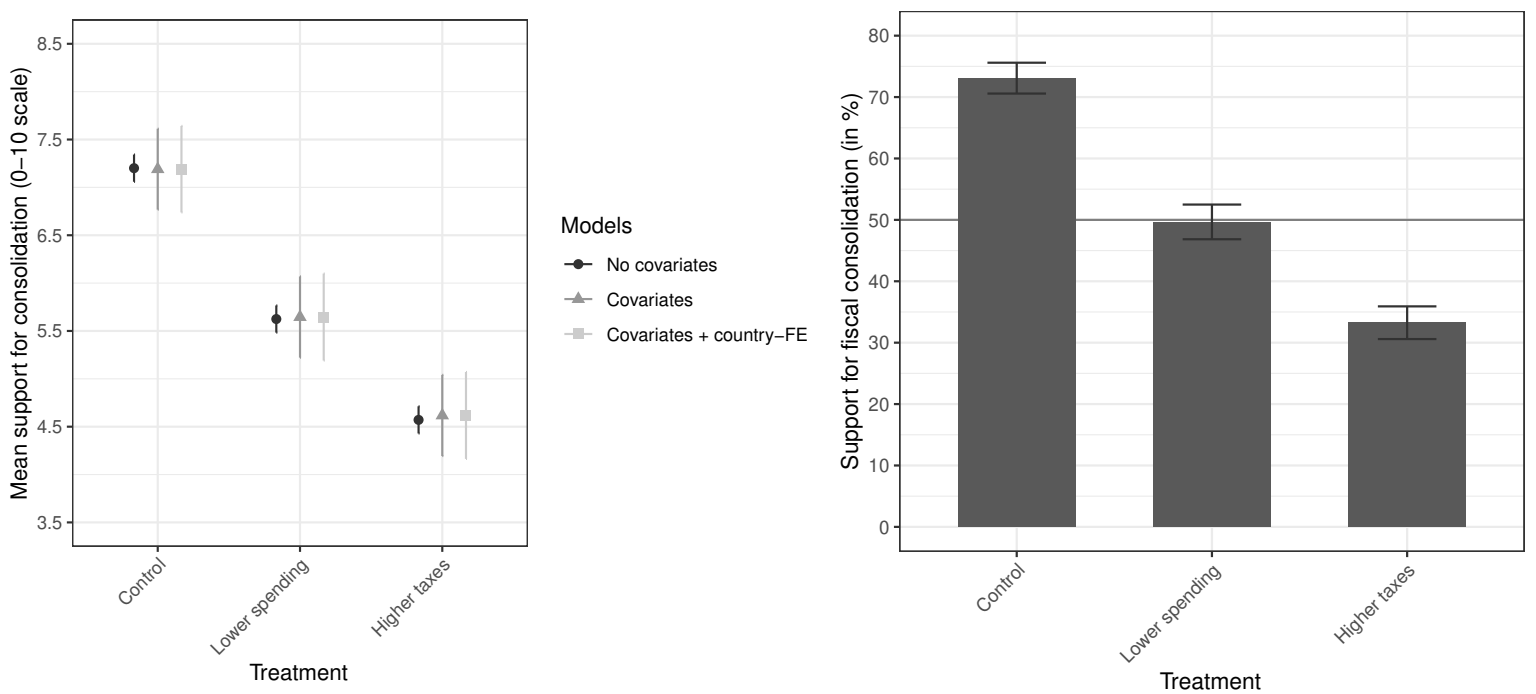

Figure 1: Predicted average support for fiscal consolidation by treatment, pooled.

Note: Predicted mean support (0-10 scale) and 95 percent confidence intervals based on OLS regressions with covariates (age, gender, marital status, having children, education, income, labor market status, union membership, and partisanship) on the left; share of respondents who support fiscal consolidation on the right.

are fiscal conservatives and, in principle, agree that the government should reduce public debt. In line with our expectation, however, citizens' support for fiscal consolidation is dramatically reduced when confronted with the necessary real-world trade-offs. While the average support for lower government debt in an unconstrained setting is 7.2 , this drops to 5.6 when it implies lower government spending. Fiscal consolidation that leads to higher taxes is even less popular, with average support for fiscal consolidation declining to 4.6. These effects are robust to the inclusion of covariates and country-fixed effects.

We dichotomized the dependent variable to estimate the share of people who support lower government debt across the three experimental groups. Since we are interested in support for fiscal consolidation, we use five as the cut-off point, i.e., responses from six to ten are counted as agreement, while responses from zero to five are counted as disagreement/neutral. The right panel of Figure 1 shows that a clear majority of 73 percent of respondents support consolidation in the control group. Support for revenue-based consolidation is a minority position (33 percent support), while support for expenditure-based fiscal policy is contested (50 percent support). 


\section{Heterogeneous support for different types of fiscal consolidation}

Figure 2 shows the support for fiscal consolidation by trade-off for different income groups and electoral constituencies. In the control group, low-income citizens are slightly less likely to support fiscal consolidation than high-income citizens. The introduction of trade-offs substantially reduces support for fiscal consolidation across all income groups. While differences across income groups turn insignificant for expenditure-based consolidation, support for revenue-based fiscal consolidation remains the highest among high-income respondents. A potential explanation for these small differences is that our very generic descriptions of revenue- or expenditure-based consolidations make it challenging to evaluate the distributive consequences.

In contrast to income, there are more substantial differences between left- and right-wing respondents. There is a substantially and significantly lower share of fiscal conservatives among left-wing than right-wing citizens (68 compared to 78 percent) in the unconstrained setting. In addition, left-wing voters also dislike more strongly both revenue- and expenditure-based fiscal consolidation than right-wing voters.

Figure 3 shows that respondents in Italy, where public debt is the highest, are the most fiscally conservative. In Germany, where public debt is the lowest, citizens are the least fiscally conservative 11 Contrary to conventional wisdom, citizens in Northwestern Europe are not more debt-averse than in Southern Europe (also see Howarth and Rommerskirchen, 2017). While the average support declines more in Spain and Italy, stark cross-national differences largely disappear in the treatment groups. There are two exceptions: support for expenditurebased consolidation is significantly lower in Spain than in the other countries, while support for revenue-based consolidation is slightly but still significantly more popular in the UK compared to Germany. The former could be related to the severity of the eurozone crisis in Spain that resulted in a general increase in support for direct public transfers, making expenditure-based

\footnotetext{
${ }^{11}$ According to the OECD, government debt (in percent of GDP) was at 153 in Italy, at 117 in the UK, at 115 in Spain, and at 72 in Germany in 2017.
} 

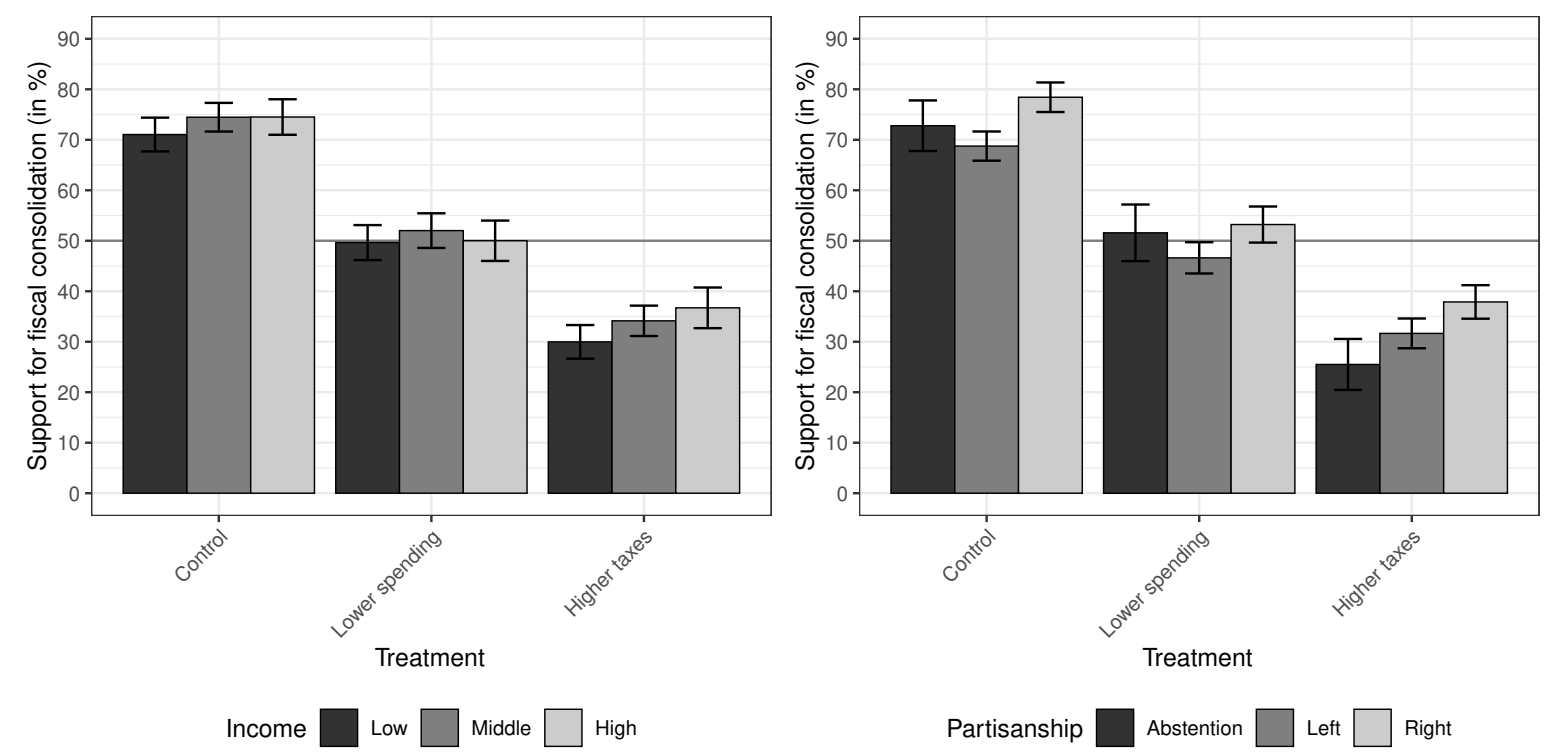

Figure 2: Support for fiscal consolidation by trade-off and income/partisanship

Note: Share of respondents who support fiscal consolidation and 95 confidence intervals by trade-off and income (left) / partisanship (right).

consolidation a clear minority position. The latter could be due to the generally lower tax levels in the UK, where citizens give the government more leeway to increase taxation than elsewhere ${ }^{12}$

In sum, support for fiscal consolidation is much lower when respondents are confronted with the inherent fiscal policy trade-offs. This is in stark contrast to Bansak et al. (2021), who find a clear majority in favor of fiscal consolidation based on their survey. Even though unconstrained support for fiscal consolidation is relatively high in principle, reducing government debt is not a priority if it implies cutting spending or increasing taxes. While both forms of fiscal consolidation are contested, citizens are more opposed to revenue-based consolidation than expenditure-based consolidation. We find only few differences across income groups, but partisanship and country differences are larger. Expenditure-based consolidation is particularly contested among leftleaning respondents and in crisis-ridden countries like Spain.

In reality, however, governments rarely pursue either expenditure-based or revenue-based consolidation exclusively. Moreover, it also matters which spending items are cut and which taxes are increased to reduce debt. Governments usually use different policy levers at the same time

\footnotetext{
${ }^{12}$ We used multivariate regressions as further robustness tests to identify additional individuallevel characteristics that correlate with people's support for fiscal consolidation (see Appendix C.3. The results confirm our subgroup findings.
} 


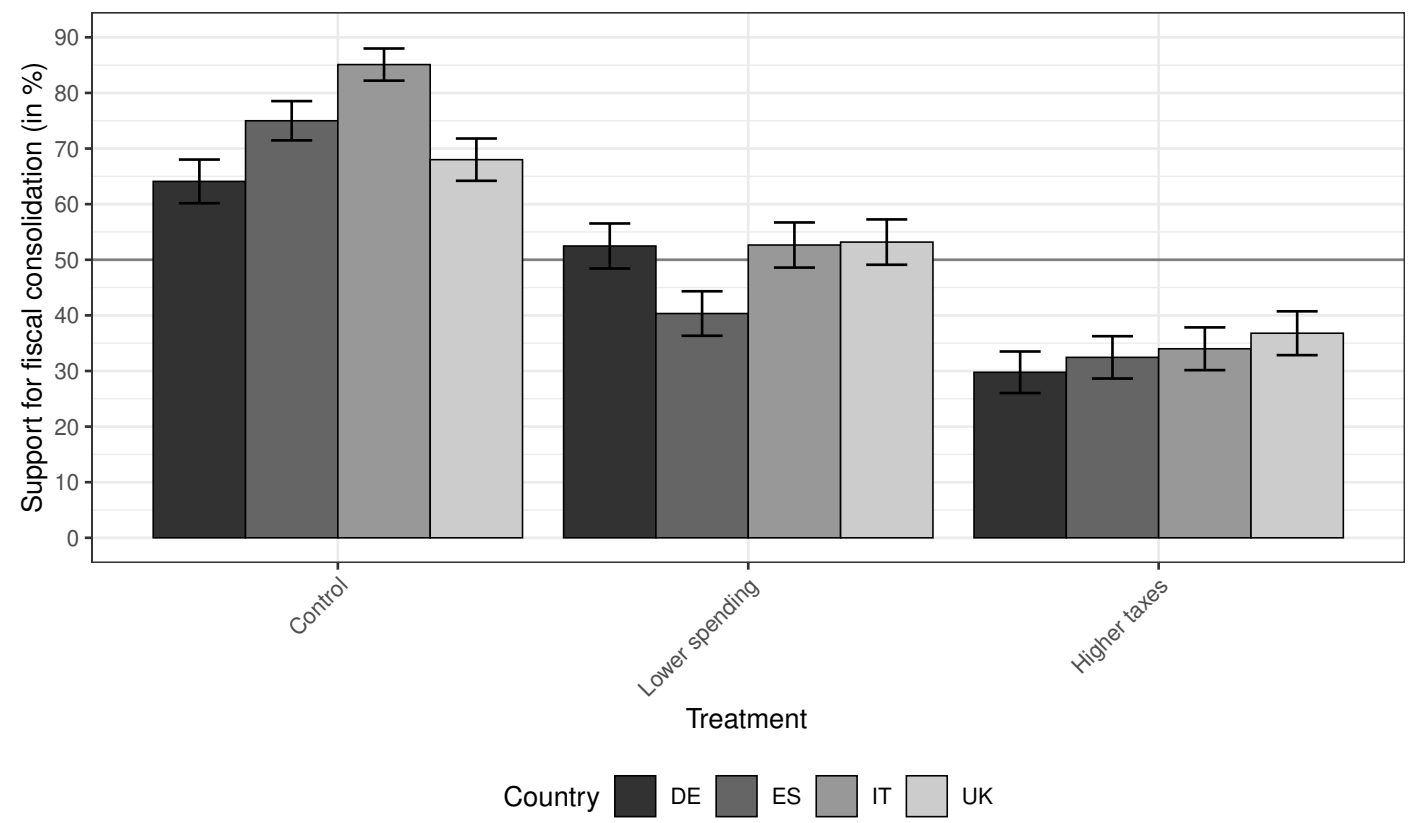

Figure 3: Support for fiscal consolidation by trade-off and country

Note: Share of respondents who support fiscal consolidation and 95 confidence intervals by trade-off and country.

to achieve their preferred outcome. To tease out the priorities of citizens in a multidimensional setting, we use a conjoint experiment.

\section{Average fiscal policy priorities}

Figure 4 shows the AMCE of increasing or decreasing spending, taxes, or debt relative to the baseline (no change) for each attribute on the probability that a given fiscal package is supported. Given that respondents have to make tough choices when completing the exercise, the figure essentially shows the average citizen's priorities. In line with our previous findings, government debt does not substantially impact the overall support for a fiscal package. Decreasing government debt has no effect, suggesting that respondents are not as fiscally conservative as the existing literature assumes. Increasing government debt reduces the likelihood that individuals support a given fiscal package, but this effect is small (1.7 percentage points relative to the baseline). The marginal means confirm that government debt is not a priority for respondents (see Appendix F.1): On average, the respondents' probability of choosing a fiscal package is 0.50 with a debt decrease, 0.49 with a debt increase, and 0.51 with no debt change. 


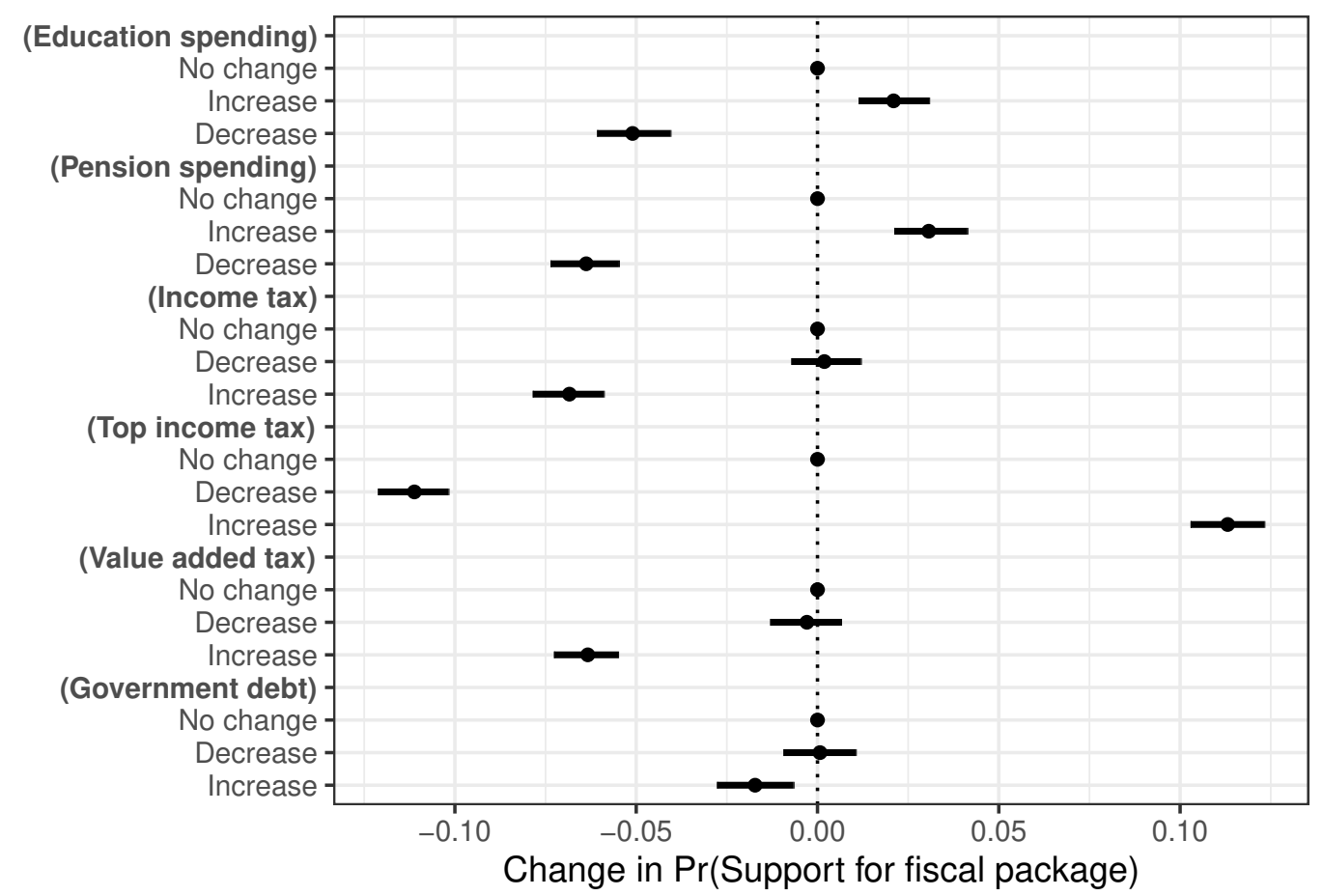

Figure 4: AMCEs from conjoint survey experiment, pooled Note: Average marginal component effect (AMCE) of a change in the value of one of our six dimensions on the probability that the respondent chooses the fiscal package.

Second, the results indicate that the average citizen is reluctant to increase general taxes or decrease government spending. Respondents strongly dislike an increase in general income tax and VAT. The former reduces support by 6.8 percentage points, while the latter lowers it by 6.4 percentage points. Similarly, lower pension and education spending also sharply reduce support for a given fiscal package. The effects of such spending cuts are smaller than the effects of general tax increases. In line with the split-sample experiment, citizens are more opposed to revenue-based than expenditure-based consolidation. Generally, respondents are firmly against both forms of fiscal consolidation in a multidimensional setting.

Third, the conjoint survey experiment also reveals the average citizen's priorities about the other side of the coin: spending increases and tax decreases. Increasing pension and education spending have a small, positive effect on support for a given fiscal package. Higher pension spending increases support by 3.1 percentage points, while higher education spending increases support by 2.1 percentage points. Surprisingly, decreasing income tax or VAT does not affect support at all, indicating that lower taxes are not as popular as commonly assumed. Most respondents consider the current level of taxes appropriate (see Ballard-Rosa et al. (2017) for a similar finding for the United States), but strongly support progressive taxes: Raising the 


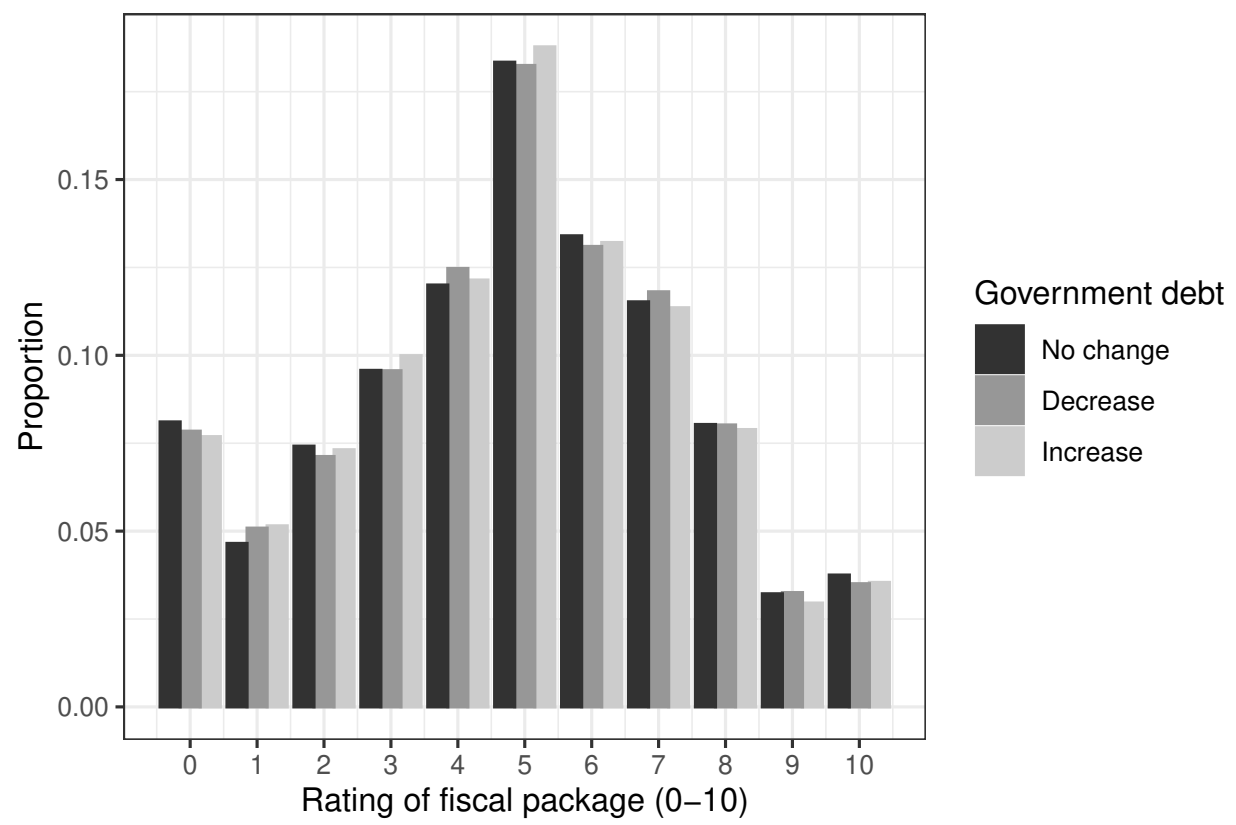

Figure 5: Distribution of the ratings of all fiscal packages by government debt attribute level Note: The dependent variable asked respondents to rate each fiscal packages on a scale from 0 to 10 .

top income tax increases support by 11.3 percentage points while reducing the top income tax lowers support by 11.1 percentage points (compared to the status quo). Thus, while revenuebased consolidation is generally very unpopular (see split-sample experiment), higher top income taxes are a clear priority. It is a more popular way to raise revenues than either increasing taxes on everyone or increasing government debt.

To verify that public debt is not a priority, we exclusively assess the importance respondents assign to this attribute. In addition to the choice-task, we asked respondents to rate each fiscal package on an 11-point Likert scale from 0 to 10. This allows us to plot the distribution of the ratings of all conjoint packages by the attribute levels for government debt in Figure 5. The results clearly show that citizens do not attach a high priority to government debt. There are barely any differences visible in how respondents rated the fiscal packages depending on whether public debt stays the same, increases, or decreases ${ }^{13}$ The distribution clearly shows that debt is not a contested issue where many respondents strongly dislike and many strongly support

${ }^{13}$ This is different for the other dimensions of our conjoint survey experiment (see Appendix F.2. 
debt. Even at the extreme ends of the distribution, there are hardly any differences in support between the different attribute levels for government debt.

In sum, the results suggest that government debt is essentially irrelevant for the evaluation of fiscal packages. Decreasing government debt is not a priority for the average citizen, who cares more about protecting the benefits from government spending without having to pay higher taxes (levied on everyone). Instead, it is a high priority for the average respondent to increase top income tax rates to finance additional spending. This latter finding should not be interpreted as evidence for the popularity of revenue-based consolidation more generally, however. Revenuebased consolidation would imply that such tax increases are used to reduce debt and not, as our findings show, to finance additional spending.

\section{Heterogeneous fiscal policy priorities}

In the last step, we use marginal means plots to elicit subgroup differences. The most striking aspect is that the differences across subgroups are relatively small. The direction of the effects does not change at all, and its magnitude remains remarkably similar. There seems to be a broad consensus about fiscal priorities.

As shown in Figure 6, government debt is not a priority for any income group, but there are a few significant differences concerning spending cuts and tax increases. Education spending is more important for high-income citizens, while pension spending is more important for mediumincome respondents. Medium-income citizens are also slightly more supportive of increasing general income taxes and top income taxes than respondents from the other groups. Although this is evidence that the strength of fiscal policy priorities varies by material interest, these differences are relatively small ${ }^{14}$

Concerning partisanship, we find that right-wing citizens are slightly more debt-averse than left-wing citizens, i.e., they are less likely to support a debt increase and more supportive of the status quo than left-wing respondents. Differences across electoral constituencies are more pronounced for the other two dimensions. First, left-wing respondents are more likely to prioritize

\footnotetext{
${ }^{14}$ Even high-income respondents favor an increase in the top income tax. Either they are altruistic or assume that they would not pay the top income tax.
} 


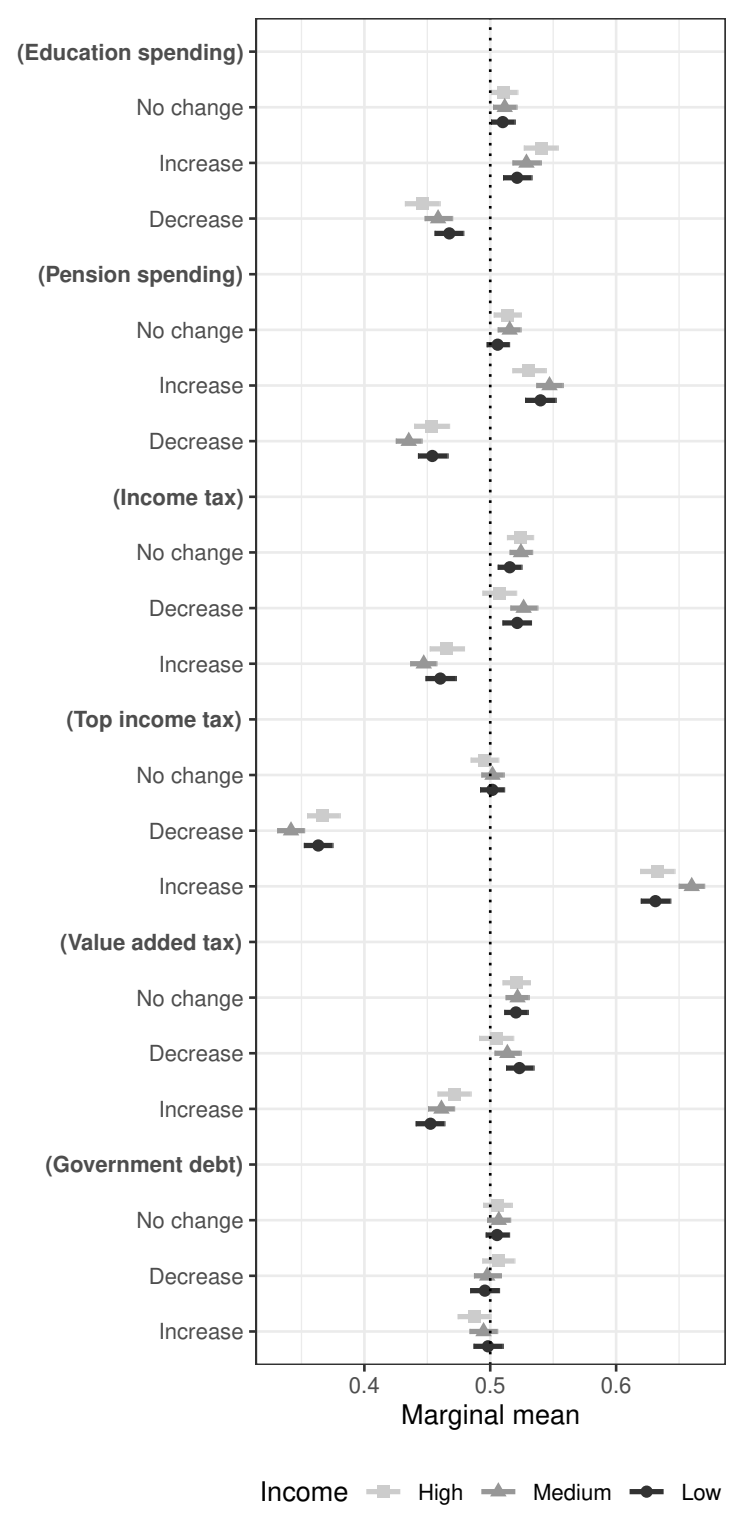

(a) By income groups

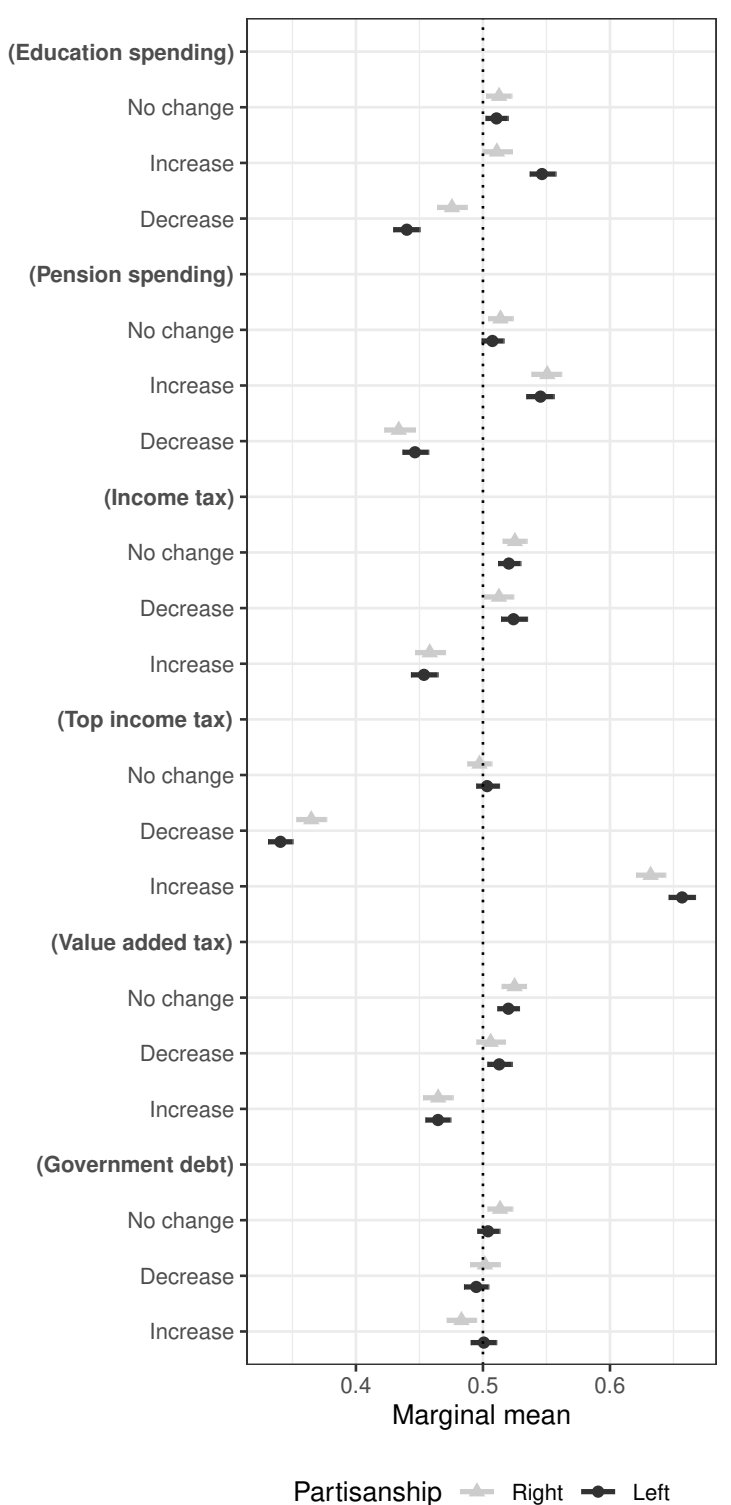

(b) By partisanship

Figure 6: Estimated marginal means from conjoint survey experiment by income group and partisanship

Note: The marginal means measure how favorable respondents are to a given feature of the reform package. 


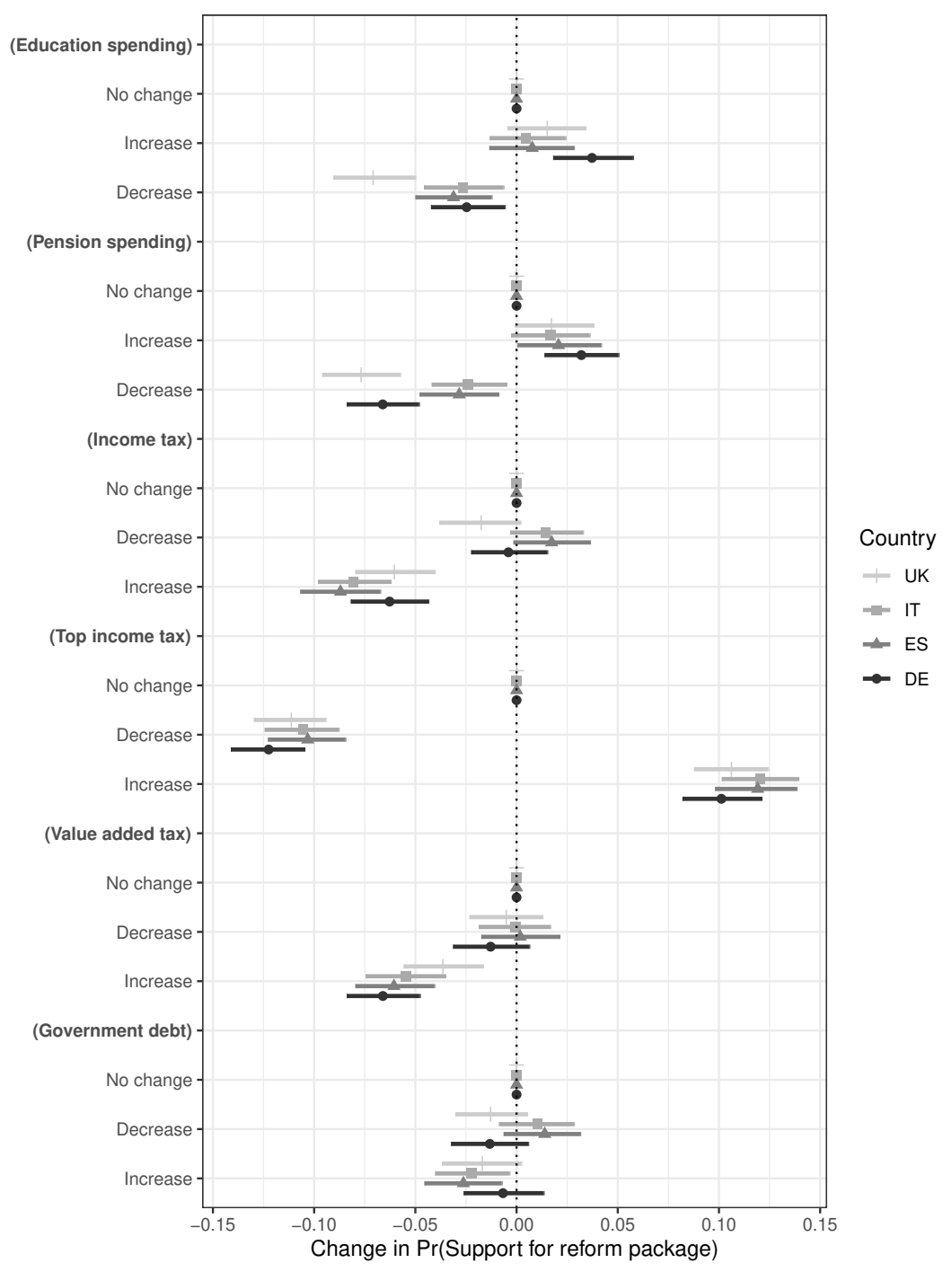

Figure 7: Estimated marginal means from the conjoint survey experiment by country

education, and this popularity of education spending for the left could explain why left-wing voters react more strongly to spending-based consolidation in the split-sample experiment. Second, left-wing respondents more strongly favor an increase in top income taxes, but it is striking that right-wing respondents also respond positively. If trade-offs are binding, a broad political coalition of citizens prefers raising top income taxes rather than cutting spending or increasing other taxes or debt. Support for pension spending and other forms of taxation are roughly similar for both groups ${ }^{15}$

\footnotetext{
${ }^{15}$ Using a general left-right measure of political ideology results in very similar findings. Moreover, there are barely any differences in support concerning other individual-level variables (e.g., occupation, wealth, education, and age), as discussed in Appendix F.1
} 
Figure 7 shows that the general pattern found above holds across the four countries, with some exceptions where we can detect statistically significant differences. German and British respondents attach a slightly higher priority to education and pension spending than their Italian and Spanish counterparts, while Italian and Spanish respondents react more sensitively to government debt. The latter confirms findings from the split-survey experiment that fiscal consolidation is supported more in the countries with higher government debt, indicating that there are likely policy feedback effects at play: In countries with a higher level of public debt (Italy and Spain), citizens presumably perceive it to be a larger risk. They have recently experienced the negative costs of a sovereign debt crisis, and, therefore, the costs of debt are more apparent.

In stark contrast to most of the unidimensional preference literature, one of the main findings of both our experiments is that subgroup differences become smaller when we introduce salient trade-offs. By studying their priorities as opposed to their unconstrained position, we show that citizens care surprisingly little about government debt.

\section{Conclusion}

We presented evidence that the inconsistent fiscal policy preferences that many scholars have identified among the public vanish when we account for the multidimensionality of fiscal policies (Hansen, 1998). Using a split-sample experiment, we showed that support for lowering government debt drops when individuals face the inherent trade-offs. In general, citizens oppose revenue-based consolidation more than expenditure-based consolidation. Left-wing voters react more strongly to expenditure-based consolidation than right-wing voters, but the reverse is not the case for revenue-based consolidation.

The findings from the conjoint survey experiment support our argument that voters do not care as much about debt as they care about government spending and taxation. The public has clear priorities, which are relatively stable across different subgroups. In a multidimensional setting with binding budget constraints, citizens are opposed to spending cuts and general tax increases. They support higher top income taxes to pay for additional spending but do not favor a reduction of debt. On average, voters on the right are more likely to oppose higher 
debt, which is also the case for people in countries with a recent sovereign debt crisis (Italy and Spain). Overall, however, priorities only vary a little across socioeconomic groups.

The paper thus makes important contributions. First, we contribute to the ongoing debate about whether people are fiscal conservatives. Our results show that, in principle, most people agree that high public debt is undesirable and support reducing it (Bansak et al., 2021). Yet, debt is not a high priority for voters, who care more about government spending and taxes. Regular opinion polls that only include unidimensional questions may consistently overstate the support for fiscal consolidation if respondents are not confronted with the real-world trade-offs that such policies entail. Therefore, political scientists should increasingly pay attention to the study of citizens' priorities instead of policy positions.

Second, our findings also help make sense of the political turmoil in Europe in the last decade. As austerity became the predominant response to the economic crisis, political actors prioritized a policy - lowering government debt - that the public cares very little about. Given that government debt is not a priority for voters and that it usually entails trade-offs, reducing it is politically risky (Baccaro et al., 2021; Bojar et al., 2021; Hübscher et al., 2021). It can have high political costs for governments that implement them. This helps to explain the rise of anti-austerity parties, movements, and politicians like Syriza, the Indignados, or Jeremy Corbyn. As government debt has soared again in the context of the COVID-19 pandemic and calls for austerity are growing louder, governments may do well to remember these costs.

Our paper, however, also raises several questions for future research. First, our survey instruments were non-political. They did not mention parties, nor did they include rhetorical justifications for different policies. However, existing research shows that voters respond to media frames (Barnes and Hicks, 2018) and elite cues (Bisgaard and Slothuus, 2018), which can make austerity popular. Parties and politicians can sell policies to voters that they do not prioritize, and they repeatedly did so in response to the Great Recession. This begs the question of whether and how opponents of austerity can use rhetorical devices to make the inherent budgetary trade-offs salient in the eyes of voters.

Second, fiscal policies may not always be salient in the first place. In times of economic crises when macroeconomic policies are politicized, politicians are likely to be punished for fiscal consolidations, but public opinion may not translate into electoral behavior when they are not. 
This raises the question of what determines the salience of fiscal policies and whether politicians can strategically time consolidation initiatives to avoid political backlash (Hübscher and Sattler, 2017). The lack of salience may also explain why governments are able to keep top income taxes low, even though our results show that people support more progressive tax systems when fiscal constraints are binding.

Finally, in the context of the COVID-19 pandemic, debates about government debt increasingly focus on debt sustainability. Although debt rose dramatically, interest rates on government bonds of most advanced economies remained extremely low. Economists emphasize that this makes high government debt more sustainable (Blanchard, 2019), but it is unclear whether voters follow arguments about debt sustainability. Future research should thus further explore the "mental models" that voters have of government debt and fiscal policy in general Stantcheva, 2021). As calls for fiscal consolidation are growing louder again, it will be crucial to better understand how voters think about rising public debt. 


\section{References}

Adolph, C., C. Breunig, and C. Koski (2020). The political economy of budget trade-offs. Journal of Public Policy 40(1), 25-50.

Alesina, A., C. Favero, and F. Giavazzi (2019). Austerity: When it Works and When it Doesn't. Princeton, NJ: Princeton University Press.

Alesina, A., R. Perotti, and J. Tavares (1998). The political economy of fiscal adjustments. Brookings Papers on Economic Activity 1998(1), 197-266.

Arias, E. and D. Stasavage (2019). How large are the political costs of fiscal austerity? The Journal of Politics 81(4), 1517-1522.

Armingeon, K. and R. Bürgisser (2021). Trade-offs between redistribution and environmental protection: the role of information, ideology, and self-interest. Journal of European Public Policy 28(4), 489-509.

Baccaro, L., B. Bremer, and E. Neimanns (2021). Till austerity do us part? a survey experiment on support for the euro in italy. European Union Politics 22(3), 401-423.

Baccaro, L. and J. Pontusson (2016). Rethinking comparative political economy: The growth model perspective. Politics 85 Society 44(2), 175-207.

Ballard-Rosa, C., L. Martin, and K. Scheve (2017). The structure of American income tax policy preferences. The Journal of Politics 79(1), 1-16.

Bansak, K., M. Bechtel, and Y. Margalit (2021). Why austerity? The mass politics of a contested policy. American Political Science Review 115(2), 486-505.

Bansak, K., J. Hainmueller, D. J. Hopkins, and T. Yamamoto (2020). Using conjoint experiments to analyze elections: The essential role of the average marginal component effect (AMCE). Available at SSRN: https://papers.ssrn.com/sol3/papers.cfm?abstract_id=3588941.

Barnes, L. (2015). The size and shape of government: Preferences over redistributive tax policy. Socio-Economic Review 13(1), 55-78.

Barnes, L., J. Blumenau, and B. E. Lauderdale (2021). Measuring attitudes toward public spending using a multivariate tax summary experiment. American Journal of Political Science, Online first, 1-17.

Barnes, L. and T. Hicks (2018). Making austerity popular: The media and mass attitudes toward fiscal policy. American Journal of Political Science 62(2), 340-354. 
Barnes, L. and T. Hicks (2021a). All Keynesians now? Public support for countercyclical government borrowing. Political Science Research and Methods 9(1), 180-188.

Barnes, L. and T. Hicks (2021b). Are policy analogies persuasive? The household budget analogy and public support for austerity. British Journal of Political Science, Online first, 1-19.

Bartels, L. M. (2016). Unequal democracy: The political economy of the new gilded age. Princeton, NJ: Princeton University Press.

Bell, D. (1976). The cultural contradictions of capitalism. New York: Basic Books.

Bisgaard, M. and R. Slothuus (2018). Partisan elites as culprits? How party cues shape partisan perceptual gaps. American Journal of Political Science 62(2), 456-469.

Blanchard, O. (2019). Public debt and low interest rates. American Economic Review 109(4), $1197-1229$.

Blinder, A. S. and D. Holtz-Eakin (1984). Public opinion and the balanced budget. American Economic Review 74(2), 144-149.

Blyth, M. (2013). Austerity: The History of a Dangerous Idea. New York, NY: Oxford University Press.

Bojar, A., B. Bremer, H. Kriesi, and C. Wang (2021). The effect of austerity packages on government popularity during the Great Recession. British Journal of Political Science, Online first, $1-19$.

Bremer, B. and R. Bürgisser (2021). Public opinion on welfare state recalibration in times of austerity: Evidence from survey experiments. Political Science Research and Methods, Conditionally Accepted.

Bremer, B., S. Hutter, and H. Kriesi (2020). Dynamics of protest and electoral politics in the great recession. European Journal of Political Research 59(4), 842-866.

Brender, A. and A. Drazen (2008). How do budget deficits and economic growth affect reelection prospects? evidence from a large panel of countries. American Economic Review 98(5), $2203-2220$.

Brooks, C. and J. Manza (2007). Why Welfare States Persist: The Importance of Public Opinion in Democracies. Chicago: University of Chicago Press.

Busemeyer, M. R. and J. L. Garritzmann (2017). Public opinion on policy and budgetary trade-offs in European welfare states: Evidence from a new comparative survey. Journal of European Public Policy 24(6), 871-889. 
Campbell, A. L. (2012). Policy makes mass politics. Annual Review of Political Science 15, $333-351$.

Cavaille, C., D. L. Chen, and K. van der Straeten (2020). Who cares? measuring preference intensity in a polarized environment. Working Paper.

Citrin, J. (1979). Do people want something for nothing: Public opinion on taxes and government spending. National Tax Journal 32, 113-129.

Copelovitch, M., J. Frieden, and S. Walter (2016). The political economy of the Euro crisis. Comparative Political Studies 49, 811-840.

Culpepper, P. D. (2011). Quiet Politics and Business Power: Corporate Control in Europe and Japan. New York, NY: Cambridge University Press.

Cusack, T. R. (1999). Partisan politics and fiscal policy. Comparative Political Studies 32(4), $464-486$

Fetzer, T. (2019). Did austerity cause Brexit? American Economic Review 109(11), 3849-86.

Galofré-Vilà, G., C. M. Meissner, M. McKee, and D. Stuckler (2021). Austerity and the rise of the nazi party. The Journal of Economic History 81(1), 81-113.

Giger, N. and M. Nelson (2011). The electoral consequences of welfare state retrenchment: Blame avoidance or credit claiming in the era of permanent austerity? European Journal of Political Research 50(1), 1-23.

Gingrich, J. and B. Ansell (2012). Preferences in context: Micro preferences, macro contexts, and the demand for social policy. Comparative Political Studies 45(12), 1624-1654.

Golden, D. G. and J. M. Poterba (1980). The price of popularity: The political business cycle reexamined. American Journal of Political Science 24(4), 696-714.

Hainmueller, J. (2012). Entropy balancing for causal effects: A multivariate reweighting method to produce balanced samples in observational studies. Political Analysis 20(1), 25-46.

Hainmueller, J., D. J. Hopkins, and T. Yamamoto (2014). Causal inference in conjoint analysis: Understanding multidimensional choices via stated preference experiments. Political Analysis 22(1), 1-30.

Hall, P. A. and D. W. Soskice (2001). Varieties of Capitalism: The Institutional Foundations of Comparative Advantage. Oxford; New York, NY: Oxford University Press.

Hanretty, C., B. E. Lauderdale, and N. Vivyan (2020). A choice-based measure of issue importance in the electorate. American Journal of Political Science 64(3), 519-535. 
Hansen, J. M. (1998). Individuals, institutions, and public preferences over public finance. The American Political Science Review 92(3), 513-531.

Häusermann, S., M. Pinggera, M. Ares, and M. Enggist (Online first, 2021). Class and social policy in the knowledge economy. European Journal of Political Research.

Hayo, B. and F. Neumeier (2016). The debt brake in the eyes of the German population. International Economics and Economic Policy 13(1), 139-159.

Hockley, G. C. and G. Harbour (1983). Revealed preferences between public expenditures and taxation cuts: Public sector choice. Journal of Public Economics 22(3), 387-399.

Hoerl, A. E. and R. W. Kennard (1970). Ridge regression: Biased estimation for nonorthogonal problems. Technometrics 12(1), 55-67.

Horiuchi, Y., D. M. Smith, and T. Yamamoto (2018). Measuring voters' multidimensional policy preferences with conjoint analysis: Application to Japan's 2014 election. Political Analysis 26(2), 190-209.

Howarth, D. and C. Rommerskirchen (2017). Inflation aversion in the European Union: exploring the myth of a North-South divide. Socio-Economic Review 15(2), 385-404.

Häusermann, S., T. Kurer, and D. Traber (2019). The politics of trade-offs: Studying the dynamics of welfare state reform with conjoint experiments. Comparative Political Studies 52(7), $1059-1095$.

Hübscher, E. and T. Sattler (2017). Fiscal consolidation under electoral risk. European Journal of Political Research 56(1), 151-168.

Hübscher, E., T. Sattler, and M. Wager (2021). Voter responses to fiscal austerity. British Journal of Political Science 51(4), 1751-1760.

Jacobs, A. M. (2011). Governing for the long term: Democracy and the politics of investment. Cambridge, New York, NY: Cambridge University Press.

Jacoby, W. G. (1994). Public attitudes toward government spending. American Journal of Political Science 38(2), 336-361.

Jacques, O. and L. Haffert (2021). Are governments paying a price for austerity? Fiscal consolidations reduce government approval. European Political Science Review 13(2), 189-207.

Kalbhenn, A. and L. Stracca (2020). Mad about austerity? The effect of fiscal consolidation on public opinion. Journal of Money, Credit and Banking 52, 531-548.

Leeper, T. J., S. B. Hobolt, and J. Tilley (2020). Measuring subgroup preferences in conjoint experiments. Political Analysis 28(2), 207-221. 
Limberg, J. (2019). What's fair? Preferences for tax progressivity in the wake of the financial crisis. Journal of Public Policy 11, 319-336.

Margalit, Y. (2013). Explaining social policy preferences: Evidence from the Great Recession. American Political Science Review 107(01), 80-103.

Meltzer, A. H. and S. F. Richard (1981). A rational theory of the size of government. Journal of Political Economy 89(5), 914-927.

Mueller, E. (1963). Public attitudes toward fiscal programs. The Quarterly Journal of Economics $77(2), 210-235$.

Nordhaus, W. D. (1975). The political business cycle. The Review of Economic Studies 42(2), 169-190.

Peltzman, S. (1992). Voters as fiscal conservatives. The Quarterly Journal of Economics 107(2), $327-361$.

Pierson, P. (1996). The new politics of the welfare state. World Politics 48(2), 143-179.

Sanders, A. (1988). Rationality, self-interest, and public attitudes on public spending. Social Science Quarterly 69(2), 311-324.

Sears, D. O. and J. Citrin (1982). Tax Revolt: Something for Nothing in California. Cambridge, MA: Harvard University Press.

Soss, J. and S. F. Schram (2007). A public transformed? Welfare reform as policy feedback. American Political Science Review 101(1), 111-127.

Stantcheva, S. (2021). Understanding tax policy: How do people reason? NBER Working Paper Series 27699, Online available at http://www.nber.org/papers/w27699, 1-44.

Stix, H. (2013). Does the broad public want to consolidate public debt? The role of fairness and of policy credibility. Kyklos 66(1), 102-129.

Svallfors, S. (1997). Worlds of welfare and attitudes to redistribution: A comparison of eight western nations. European Sociological Review 13(3), 283-304.

Talving, L. (2017). The electoral consequences of austerity: economic policy voting in Europe in times of crisis. West European Politics 40(3), 560-583.

Welch, S. (1985). The "more for less" paradox: Public attitudes on taxing and spending. Public Opinion Quarterly 49(3), 310-316. 
Supplementary Information/Online Appendixes

Do Citizens Care About Government Debt?

Evidence from Survey Experiments on Budgetary Priorities

December 2021 


\section{Table of Contents}

\begin{tabular}{|lll}
\hline A Operationalization, survey flow, and summary statistics & A2
\end{tabular}

B Case selection, sampling, and quality tests $\quad$ A5

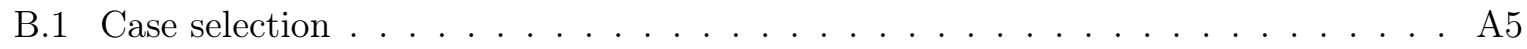

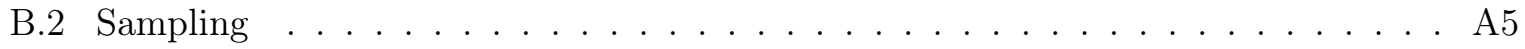

B.3 Quality checks and screening out of respondents . . . . . . . . . . . . . A7

B.4 Balance tests for the split-sample experiment $\ldots \ldots \ldots \ldots \ldots$ A $\ldots \ldots$

\begin{tabular}{lll}
\hline C Additional results from the split-sample experiments & A10
\end{tabular}

C.1 Mean plots for support for fiscal consolidation by income, partisanship, and country A10

C.2 Tests for other heterogeneous treatment effects from the split-sample experiment A11

C.3 $\quad$ OLS regression analysis for split-sample experiment . . . . . . . . . . . . . . . . . A12

\begin{tabular}{|l|l|}
\hline D Instructions for the conjoint survey experiment & A15
\end{tabular}

\begin{tabular}{|lll}
\hline E & Explanation of ridge regression to analyze the conjoint experiment & A17
\end{tabular}

\begin{tabular}{lll}
\hline F & Additional results from the conjoint experiment & A20
\end{tabular}

F.1 Marginal mean plots from the conjoint experiment . . . . . . . . . . . . A A20

F.2 Distribution plots based on rating variable $\ldots \ldots \ldots \ldots$. . . . . . . . . A21

F.3 Conjoint analysis with the rating variable $\ldots \ldots \ldots \ldots \ldots$. . . . . . . . . 22

F.4 Tests for other heterogeneous treatment effects from the conjoint experiment. . . A23

\begin{tabular}{ll}
\hline G Analysis with entropy balancing & A26
\end{tabular}

\begin{tabular}{ll}
\hline H Robustness tests for the conjoint survey experiment & A30
\end{tabular} 


\section{A Operationalization, survey flow, and summary statistics}

Table A.1: Operationalization of variables

\begin{tabular}{|c|c|c|}
\hline Variable & Question wording & Measurement \\
\hline Age & What year were you born? & Numerical variable: $18-88$ \\
\hline Female & What is your sex? & $\begin{array}{l}\text { Binary variable: } 1 \text { female; } 0 \text { men } \\
\text { or no answer }\end{array}$ \\
\hline Married & What is your marital status? & $\begin{array}{l}\text { Binary variable: } 1 \text { married; } 0 \text { not } \\
\text { married }\end{array}$ \\
\hline Children & $\begin{array}{l}\text { How many children are living in your } \\
\text { household? }\end{array}$ & $\begin{array}{l}\text { Binary variable: } 1 \text { children; } 0 \text { no } \\
\text { children }\end{array}$ \\
\hline Education & $\begin{array}{l}\text { What is the highest level of education that } \\
\text { you have achieved so far? }\end{array}$ & $\begin{array}{l}\text { Categorical variable: } 1 \text { primary / } \\
\text { lower secondary; } 2 \text { secondary; } 3 \\
\text { tertiary }\end{array}$ \\
\hline Class* & What is/was your occupation? & $\begin{array}{l}\text { Categorical variable: } 1=\mathrm{em}- \\
\text { ployer; } 2=\text { middle class; } 3= \\
\text { working class; } 4=\text { routine worker }\end{array}$ \\
\hline Income & $\begin{array}{l}\text { Please indicate the answer that includes } \\
\text { your total household income in the pre- } \\
\text { vious month, after taxes and compulsory } \\
\text { deductions. }\end{array}$ & $\begin{array}{l}\text { Numerical variable by percentile: } \\
\text { 1-10 OR categorical variable by } \\
\text { percentile: } 1 \text { 1st-3rd; } 24 \text { th-7th; } \\
3 \text { 8th-10th }\end{array}$ \\
\hline Unemployed & $\begin{array}{l}\text { Which of these descriptions applies to } \\
\text { what you have been doing for the last } \\
\text { months? }\end{array}$ & $\begin{array}{l}\text { Binary variable: } 1 \text { unemployed; } 0 \\
\text { otherwise }\end{array}$ \\
\hline Retired & $\begin{array}{l}\text { Which of these descriptions applies to } \\
\text { what you have been doing for the last } \\
\text { months? }\end{array}$ & $\begin{array}{l}\text { Binary variable: } 1 \text { retried; } 0 \text { oth- } \\
\text { erwise }\end{array}$ \\
\hline Union & $\begin{array}{l}\text { Are you or have you ever been a member } \\
\text { of a trade union or similar organization? }\end{array}$ & $\begin{array}{l}\text { Binary variable: } 1 \text { current union } \\
\text { member; } 0 \text { otherwise }\end{array}$ \\
\hline Partisanship* & $\begin{array}{l}\text { Which party did you vote for in } \\
\text { the last (COUNTRY) election in } \\
\text { (MONTH/YEAR)? }\end{array}$ & $\begin{array}{l}\text { Categorical variable: } 1 \text { far left; } 2 \\
\text { center left; } 3 \text { center right; } 4 \text { far } \\
\text { right; } 5 \text { other party; } 0 \text { abstention }\end{array}$ \\
\hline $\begin{array}{l}\text { Left-right } \\
\text { scale }\end{array}$ & $\begin{array}{l}\text { Where would you place yourself, where } 0 \\
\text { means the left and } 10 \text { means the right? }\end{array}$ & $\begin{array}{l}\text { Categorical variable: } 0-4 \text { left; } 5-6 \\
\text { center; } 7-10 \text { right }\end{array}$ \\
\hline $\begin{array}{l}\text { Political in- } \\
\text { terest }\end{array}$ & $\begin{array}{l}\text { How interested are you in politics on a } \\
\text { scale from } 0 \text { to } 10 \text { ? }\end{array}$ & Numerical variable: $0-10$ \\
\hline Political trust & $\begin{array}{l}\text { How much do you personally trust the } \\
\text { (COUNTRY) government? }\end{array}$ & Numerical variable: $0-10$ \\
\hline $\begin{array}{l}\text { Home owner- } \\
\text { ship }\end{array}$ & $\begin{array}{l}\text { About how much money would be left if } \\
\text { the home or apartment you and/or your } \\
\text { immediate family live in was sold, and any } \\
\text { debts on it, such as mortgage or personal } \\
\text { loan, would have been paid off? }\end{array}$ & $\begin{array}{l}\text { Binary variable: } 1 \text { creditor (pos- } \\
\text { itive wealth from home owner- } \\
\text { ship); } 0 \text { debtor (negative or no } \\
\text { wealth from home ownership) }\end{array}$ \\
\hline $\begin{array}{l}\text { Asset owner- } \\
\text { ship }\end{array}$ & $\begin{array}{l}\text { About how much money would be left if } \\
\text { you and/or your immediate family con- } \\
\text { verted to cash all savings, stocks, or bonds } \\
\text { you own, and then paid off any personal } \\
\text { debts you have (excl. home loan)? }\end{array}$ & $\begin{array}{l}\text { Binary variable: } 1 \text { creditor (posi- } \\
\text { tive wealth from assets); } 0 \text { debtor } \\
\text { (negative or no wealth from as- } \\
\text { sets) }\end{array}$ \\
\hline
\end{tabular}

Note: ${ }^{*}$ Please see next page for further information on the exact operationalization. 
Class was coded according to the following occupational groups: (1) small and large employers: selfemployed farmers, fishermen, professionals, owner shop/business proprietor; (2) middle classes: employed professionals, general management, middle management, employed position desk with upper secondary education, employed position travelling with upper secondary education and employed position service with upper secondary; (3) working classes: skilled manual workers, supervisors and unskilled workers with an upper secondary education; (4) routine workers: unskilled worker without upper secondary, employed position desk without upper secondary education, employed position travel- ling without upper secondary education and employed position service without upper secondary

Partisanship was coded according to the ParlGov database, which classifies parties into families by their position in an economic (state/market) and a cultural (liberty/authority) left/right dimension. The party families were then simplified into five political groups, as shown below. For some subgroup analyses analyses, we further simplify partisanship into the following three categories by dropping respondents who support other parties: left (far left, center left), right (far right, center right), abstention.

Table A.2: Classification of political parties into five groups

\begin{tabular}{|c|c|c|c|c|}
\hline & Germany & Italy & Spain & UK \\
\hline $\begin{array}{l}\text { Far } \\
\text { right }\end{array}$ & $\mathrm{AfD}$ & $\begin{array}{l}\text { Lega Nord, } \\
\text { Fratelli d'Italia }\end{array}$ & & $\begin{array}{l}\text { UK Independence } \\
\text { Party }\end{array}$ \\
\hline $\begin{array}{l}\text { Center } \\
\text { right }\end{array}$ & CDU, CSU, FDP & $\begin{array}{l}\text { SC, Nuovo Cen- } \\
\text { trodestra, Forza } \\
\text { Italia }\end{array}$ & $\begin{array}{l}\text { PP, Ciudadanos, } \\
\text { Convergencia, } \\
\text { EAJ-PNV, CC- } \\
\text { PNC }\end{array}$ & $\begin{array}{l}\text { Conservative, } \\
\text { Liberal } \\
\text { Democrats }\end{array}$ \\
\hline $\begin{array}{l}\text { Center } \\
\text { left }\end{array}$ & $\begin{array}{l}\text { SPD, } \\
\text { Grüne/Bündnis90 }\end{array}$ & $\begin{array}{ll}\text { PD, } & \text { Radicali } \\
\text { Italiani, } & \text { Articolo } \\
1 / \mathrm{MDP} & \\
\end{array}$ & PSOE & $\begin{array}{l}\text { Labour, SNP, } \\
\text { Greens }\end{array}$ \\
\hline Far left & Die Linke & $\begin{array}{l}\text { Sinistra Ital- } \\
\text { iana, Movimento } \\
\text { Cinque Stelle, } \\
\text { Rifondazione } \\
\text { Comunista }\end{array}$ & $\begin{array}{l}\text { Unidos Podemos, } \\
\text { En Comu Podem, } \\
\text { Compromis- } \\
\text { Podemos-EUPV, } \\
\text { En Marea, EH } \\
\text { Bildu }\end{array}$ & \\
\hline Others & Piratenpartei & $\begin{array}{l}\text { Südtiroler } \\
\text { Volkspartei }\end{array}$ & ERC & Plaid Cymru \\
\hline
\end{tabular}




\section{Survey Flow:}

- Basic survey information and consent form

- Demographic questions (age, household size, children, marital status, urban-rural)

- Political and socio-economic questions (left-right, vote choice, education level, income, occupation, employment, asset/house ownership, ...)

- Conjoint experiment

- Split experiment

\section{Summary Statistics:}

Table A.3: Summary statistics

\begin{tabular}{lrrrrr}
\hline \hline Statistic & $\mathrm{N}$ & Mean & St. Dev. & Min & Max \\
\hline Fiscal consolidation (control) & 1,200 & 7.201 & 2.326 & 0 & 10 \\
Fiscal consolidation (lower spending) & 1,204 & 5.625 & 2.583 & 0 & 10 \\
Fiscal consolidation (higher taxes) & 1,203 & 4.571 & 2.615 & 0 & 10 \\
Age & 4,800 & 46.670 & 15.851 & 18 & 88 \\
Female & 4,797 & 0.512 & 0.500 & 0 & 1 \\
Married & 4,800 & 0.480 & 0.500 & 0 & 1 \\
Children & 4,800 & 0.434 & 0.496 & 0 & 1 \\
Education & 4,785 & 2.249 & 0.674 & 1 & 3 \\
Occupation & 4,051 & 2.175 & 0.819 & 1 & 4 \\
Income & 4,595 & 5.177 & 2.805 & 1 & 10 \\
Unemployed & 4,768 & 0.072 & 0.259 & 0 & 1 \\
Retired & 4,800 & 0.197 & 0.398 & 0 & 1 \\
Union & 4,738 & 0.253 & 0.435 & 0 & 1 \\
Partisanship & 4,488 & 2.156 & 1.336 & 0 & 5 \\
Left-right placement & 4,800 & 1.817 & 0.743 & 1 & 3 \\
Interest & 4,800 & 5.928 & 2.686 & 0 & 10 \\
Trust & 4,800 & 3.453 & 2.686 & 0 & 10 \\
House ownership & 4,107 & 1.282 & 0.928 & 0 & 2 \\
Asset ownership & 4,066 & 1.311 & 0.913 & 0 & 2 \\
\hline \hline
\end{tabular}




\section{B Case selection, sampling, and quality tests}

\section{B.1 Case selection}

Table A.4: Case selection

\begin{tabular}{l|l|l|l|l}
\hline \hline & DE & IT & ES & UK \\
\hline Welfare regime & Continental & Southern & Southern & Liberal \\
Varieties of capitalism & CME & MME & MME & LME \\
Unemployment rate & 3.7 & 11.2 & 17.2 & 4.3 \\
Youth unemployment rate & 6.8 & 34.8 & 38.7 & 12.1 \\
Government debt (\% of GDP) & 72 & 153 & 115 & 117 \\
Education spending (\% of & 3.6 & 3.3 & 3.5 & 4.2 \\
GDP) & & 16.2 & 11.0 & 6.2 \\
Pension spending (\% of GDP) & 10.1 & & \\
\hline
\end{tabular}

Notes: (Youth) unemployment rate and government debt from 2017; education and pension spending from 2015 (all OECD data).

\section{B.2 Sampling}

Our survey was fielded in four large European countries in January 2018: Germany, Italy, Spain, and the United Kingdom. In each country, 1,200 respondents were recruited to participate in the survey. A large online panel provided by Qualtrics was used with tens of thousands of panelists across all age brackets. Qualtrics only uses double-opt in online panels that allow their panelists to take a survey no more than once every two weeks. Respondents were then drawn from a pool of eligible voters in each country and the sample was representative of all eligible voters based on gender and age, meaning we introduced quota sampling based on age and gender.

Given our subgroups comparisons, we are particularly interested in having roughly representative income and partisan groups. Even without quotas sampling by income and ideology, our sample is already fairly representative in terms of both variables. Figure A.1 plots the share of respondents by income decile for all countries (left) and by country (right). Overall, our income variable is almost equally distributed across income decile, only with a slightly higher representation of low-income respondents compared to high-income respondents. While the German and the Spanish samples are quite well balanced across income decile, the Italian and British samples are slightly more skewed towards low-income respondents. However, the differences are overall not particularly large. 
In addition, we compared the party vote share in the closest election to the share of voters in our survey. We distinguish between the far right, center right, center left, and the far left, as explained in more detail in Table A.2. Especially in Italy and Spain, our sample matches the actual vote share that these four blocks received very well. In Germany, far left and center left voters are slightly over-represented, while center right voters are underrepresented. In the United Kingdom, center right voters are also underrepresented while center left and far right voters are slightly over-represented. Overall, the survey vote share matches fairly well the actual vote share.
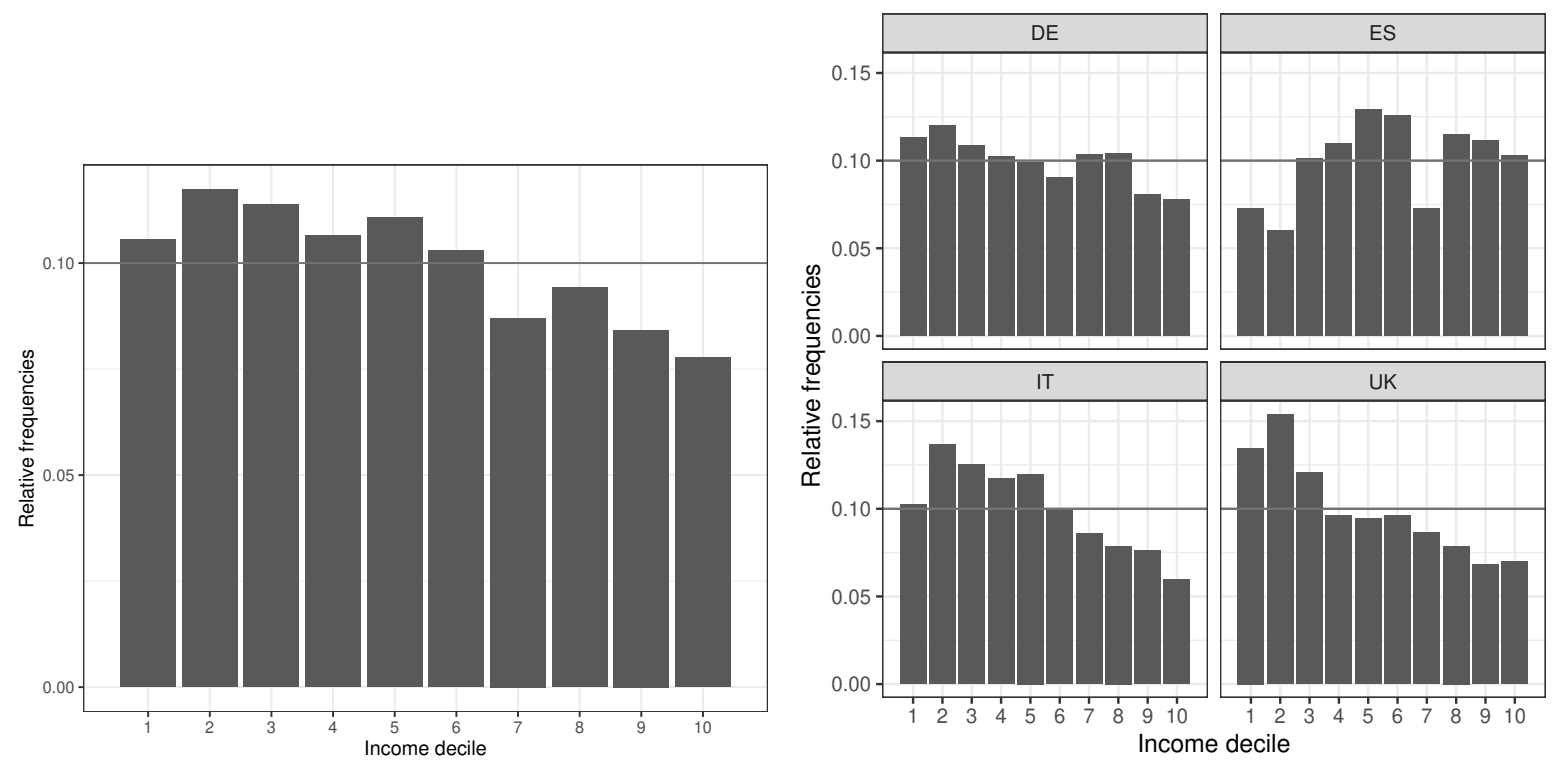

Figure A.1: Share of respondents by income decile (left: all countries; right: by country)

Table A.5: Survey vote share versus actual vote share

\begin{tabular}{ll|l|l|l|l}
\hline \hline & Far Left & $\begin{array}{l}\text { Center } \\
\text { Left }\end{array}$ & $\begin{array}{l}\text { Center } \\
\text { Right }\end{array}$ & $\begin{array}{l}\text { Far } \\
\text { Right }\end{array}$ \\
\hline \multirow{4}{*}{ DE } & Election & 9.2 & 29.4 & 43.7 & 12.6 \\
& Survey & 15.9 & 32.1 & 33.2 & 11.2 \\
& Diff. & 6.7 & 2.7 & -10.5 & -1.4 \\
\hline \multirow{4}{*}{ ES } & Election & 21.1 & 22.7 & 46.1 & 0.0 \\
& Survey & 25.1 & 18.4 & 45.4 & 0.0 \\
& Diff. & 4.0 & -4.3 & -0.7 & 0.0 \\
\hline \multirow{4}{*}{ IT } & Election & 34.4 & 22.2 & 18.8 & 21.8 \\
& Survey & 38.5 & 22.1 & 15.6 & 19.9 \\
& Diff. & 4.1 & -0.1 & -3.2 & -1.9 \\
\hline \multirow{4}{*}{ UK } & Election & 0.0 & 47.0 & 49.9 & 1.8 \\
& Survey & 0.0 & 51.6 & 40.9 & 5.7 \\
& Diff. & 0.0 & 4.6 & -9.0 & 3.9 \\
\hline \hline
\end{tabular}


We also used weights to match the demographic characteristics of the population in each country as closely as possible using entropy balancing (Hainmueller 2012). Please see Appendix $\mathrm{G}$ for a detailed explanation and the presentation of the results using entropy balancing.

\section{B.3 Quality checks and screening out of respondents}

To ensure the quality of our sample, the survey included an attention check and a speeding check. We implemented a common attention check in the middle of the survey. Respondents were shown the following question:

We are interested in learning about your preferences on a variety of topics, including colours. To demonstrate that you have read this question, please go ahead and select both red and green from the alternatives below, no matter what your favourite color is. Yes, ignore the question below and select both of those options. What is your favourite color?

The answer options were: blue, red, purple, orange, yellow, green, brown, gray. Those who did not select the two correct color, were excluded from the survey. Additionally, we implemented a speeding check for the whole survey and one specifically for the conjoint experiment. Respondents who had a response time below $1 / 3$ of the median response time were excluded. Overall, 712 respondents failed the attention check and 394 respondents failed the speeding checks (104 for overall speeding, 290 for conjoint speeding). 
B.4 Balance tests for the split-sample experiment

\begin{tabular}{l|llll|ll}
\hline \hline \multirow{2}{*}{ Variable } & \multicolumn{3}{c}{ Control } & \multicolumn{2}{c}{ Lower spending } & \multicolumn{2}{c}{ Higher taxes } \\
& Mean & SD & Mean & SD & Mean & SD \\
\hline Age & 46.28 & 15.83 & 46.30 & 15.85 & 47.08 & 16.03 \\
Female & 0.54 & 0.50 & 0.52 & 0.50 & 0.48 & 0.50 \\
Married & 0.48 & 0.50 & 0.49 & 0.50 & 0.49 & 0.50 \\
Children & 0.44 & 0.50 & 0.45 & 0.50 & 0.44 & 0.50 \\
Education & 2.28 & 0.68 & 2.24 & 0.67 & 2.25 & 0.67 \\
Occupation & 2.16 & 0.80 & 2.16 & 0.82 & 2.20 & 0.84 \\
Income & 5.30 & 2.81 & 5.15 & 2.86 & 5.16 & 2.76 \\
Unemployment & 0.07 & 0.25 & 0.07 & 0.26 & 0.08 & 0.27 \\
Retired & 0.19 & 0.39 & 0.20 & 0.40 & 0.20 & 0.40 \\
Union & 0.25 & 0.43 & 0.25 & 0.43 & 0.26 & 0.44 \\
\hline \hline
\end{tabular}


Table A.6: Balance tests comparing treatment groups with the control group (linear probability models)

\begin{tabular}{|c|c|c|c|c|}
\hline & \multicolumn{4}{|c|}{ Treatment $=1$, Control $=0$} \\
\hline & Lower spending & Lower spending & Higher taxes & Higher taxes \\
\hline & $(1)$ & $(2)$ & $(3)$ & $(4)$ \\
\hline \multirow[t]{2}{*}{ Age } & 0.0001 & 0.0000 & 0.0001 & 0.0000 \\
\hline & $(0.001)$ & $(0.001)$ & $(0.001)$ & $(0.001)$ \\
\hline \multirow[t]{2}{*}{ Female } & -0.02 & -0.02 & -0.02 & -0.02 \\
\hline & $(0.02)$ & $(0.02)$ & $(0.02)$ & $(0.02)$ \\
\hline \multirow{2}{*}{ Married } & 0.05 & 0.05 & 0.05 & 0.05 \\
\hline & $(0.03)$ & $(0.03)$ & $(0.03)$ & $(0.03)$ \\
\hline \multirow[t]{2}{*}{ Children } & 0.01 & 0.003 & 0.01 & 0.003 \\
\hline & $(0.03)$ & $(0.03)$ & $(0.03)$ & $(0.03)$ \\
\hline \multicolumn{5}{|c|}{ Education (ref: primary/lower secondary) } \\
\hline Secondary & $\begin{array}{c}-0.02 \\
(0.04)\end{array}$ & $\begin{array}{c}-0.03 \\
(0.04)\end{array}$ & $\begin{array}{c}-0.02 \\
(0.04)\end{array}$ & $\begin{array}{c}-0.03 \\
(0.04)\end{array}$ \\
\hline \multirow[t]{2}{*}{ Tertiary } & -0.06 & -0.07 & -0.06 & -0.07 \\
\hline & $(0.04)$ & $(0.04)$ & $(0.04)$ & $(0.04)$ \\
\hline \multicolumn{5}{|c|}{ Class (ref: Working Class) } \\
\hline \multirow[t]{2}{*}{. Employer } & 0.07 & 0.06 & 0.07 & 0.06 \\
\hline & $(0.04)$ & $(0.04)$ & $(0.04)$ & $(0.04)$ \\
\hline \multirow[t]{2}{*}{ Middle Class } & 0.05 & 0.05 & 0.05 & 0.05 \\
\hline & $(0.04)$ & $(0.04)$ & $(0.04)$ & $(0.04)$ \\
\hline \multirow{2}{*}{ Routine Worker } & 0.06 & 0.06 & 0.06 & 0.06 \\
\hline & $(0.05)$ & $(0.05)$ & $(0.05)$ & $(0.05)$ \\
\hline \multirow[t]{2}{*}{ Income } & -0.004 & -0.004 & -0.004 & -0.004 \\
\hline & $(0.005)$ & $(0.005)$ & $(0.005)$ & $(0.005)$ \\
\hline \multirow[t]{2}{*}{ Unemployed } & -0.03 & -0.03 & -0.03 & -0.03 \\
\hline & $(0.05)$ & $(0.05)$ & $(0.05)$ & $(0.05)$ \\
\hline \multirow[t]{2}{*}{ Retired } & -0.01 & -0.01 & -0.01 & -0.01 \\
\hline & $(0.04)$ & $(0.04)$ & $(0.04)$ & $(0.04)$ \\
\hline \multirow[t]{2}{*}{ Union membership } & -0.02 & -0.01 & -0.02 & -0.01 \\
\hline & $(0.03)$ & $(0.03)$ & $(0.03)$ & $(0.03)$ \\
\hline \multicolumn{5}{|c|}{ Partisanship (ref: Center Left) } \\
\hline \multirow[t]{2}{*}{ Far left } & $-0.08^{*}$ & $-0.09 *$ & $-0.08^{*}$ & $-0.09^{*}$ \\
\hline & $(0.04)$ & $(0.04)$ & $(0.04)$ & $(0.04)$ \\
\hline \multirow[t]{2}{*}{ Center Right } & -0.03 & -0.02 & -0.03 & -0.02 \\
\hline & $(0.03)$ & $(0.03)$ & $(0.03)$ & $(0.03)$ \\
\hline Far right & -0.09 & $-0.10^{*}$ & -0.09 & $-0.10^{*}$ \\
\hline & $(0.05)$ & $(0.05)$ & $(0.05)$ & $(0.05)$ \\
\hline Other party & 0.06 & 0.05 & 0.06 & 0.05 \\
\hline & $(0.06)$ & $(0.06)$ & $(0.06)$ & $(0.06)$ \\
\hline Abstention & -0.01 & -0.01 & -0.01 & -0.01 \\
\hline & $(0.04)$ & $(0.04)$ & $(0.04)$ & $(0.04)$ \\
\hline Country (ref: Germar & & & & \\
\hline Spain & & 0.01 & & 0.01 \\
\hline & & $(0.03)$ & & $(0.03)$ \\
\hline Italy & & 0.03 & & 0.03 \\
\hline & & $(0.04)$ & & $(0.04)$ \\
\hline . UK & & 0.001 & & 0.001 \\
\hline & & $(0.04)$ & & $(0.04)$ \\
\hline Constant & $0.53^{* * *}$ & $0.53^{* * *}$ & $0.53^{* * *}$ & $0.53^{* * *}$ \\
\hline & $(0.07)$ & $(0.08)$ & $(0.07)$ & $(0.08)$ \\
\hline Country fixed effects & No & Yes & No & Yes \\
\hline Observations & 1,840 & 1,840 & 1,840 & 1,840 \\
\hline $\mathrm{R}^{2}$ & 0.01 & 0.01 & 0.01 & 0.01 \\
\hline Adjusted $\mathrm{R}^{2}$ & 0.001 & -0.0004 & 0.001 & -0.0004 \\
\hline Residual Std. Error & 0.50 & 0.50 & 0.50 & 0.50 \\
\hline F Statistic & 1.09 & 0.97 & 1.09 & 0.97 \\
\hline
\end{tabular}




\section{Additional results from the split-sample experiments}

\section{C.1 Mean plots for support for fiscal consolidation by income, partisanship, and country}
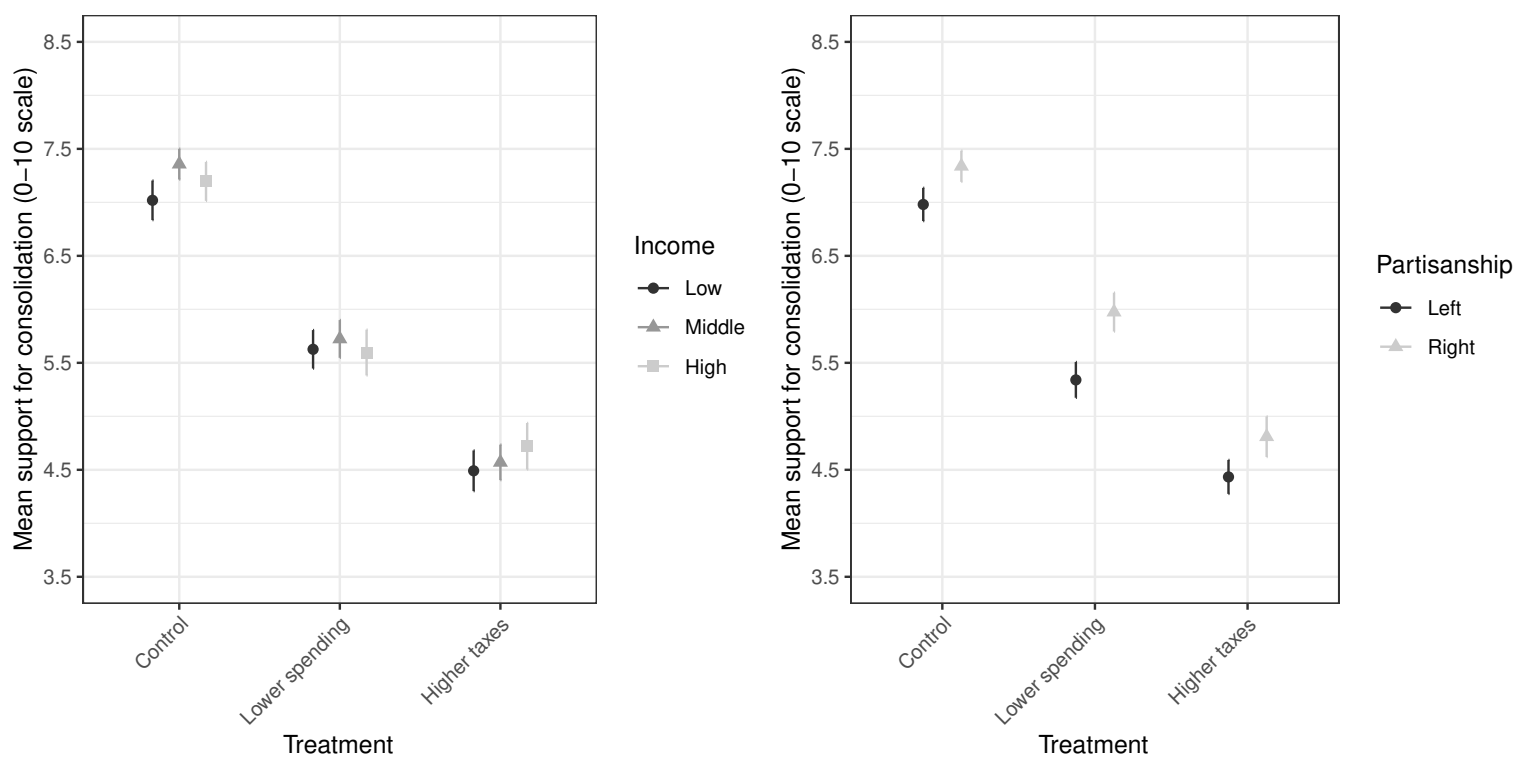

Figure A.2: Average support for fiscal consolidation by trade-off and income/partisanship

Note: Mean support levels and 95 confidence intervals by trade-off and income/partisanship. The left-hand side distinguishes between three income groups based on the relative income distribution in each country; the right-hand side distinguishes between left- and right-wing voters.

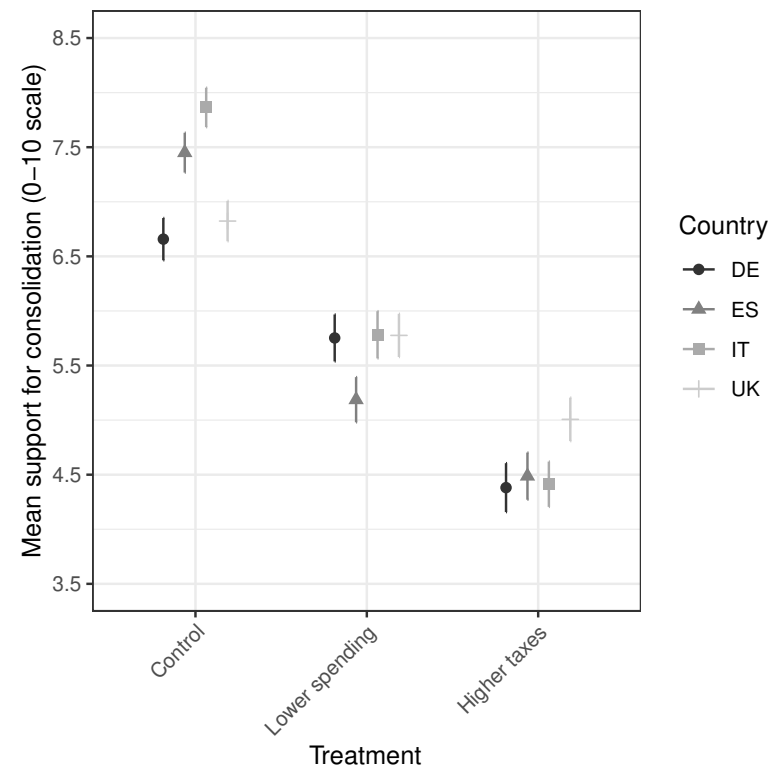

Figure A.3: Average support for fiscal consolidation by trade-off and country

Note: Mean support levels and 95 confidence intervals for fiscal consolidation by trade-off and country. 


\section{C.2 Tests for other heterogeneous treatment effects from the split-sample experiment}
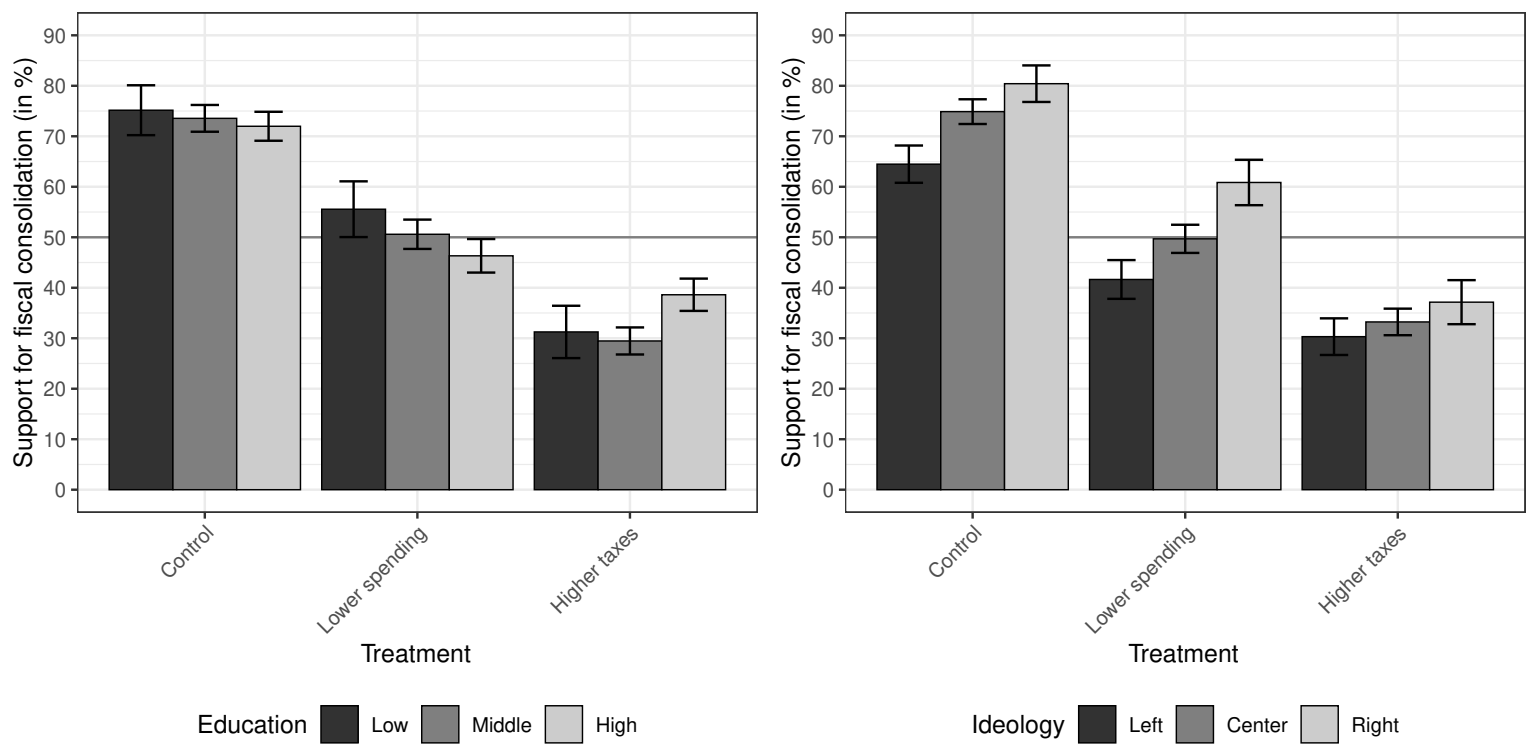

Figure A.4: Support for fiscal consolidation by trade-off and education/ideology

Note: Share of respondents who support fiscal consolidation and 95 confidence intervals by tradeoff and education/ideology. The left-hand side distinguishes between three education groups; the right-hand side distinguishes between three ideological groups based on respondents' left-right self-placement.

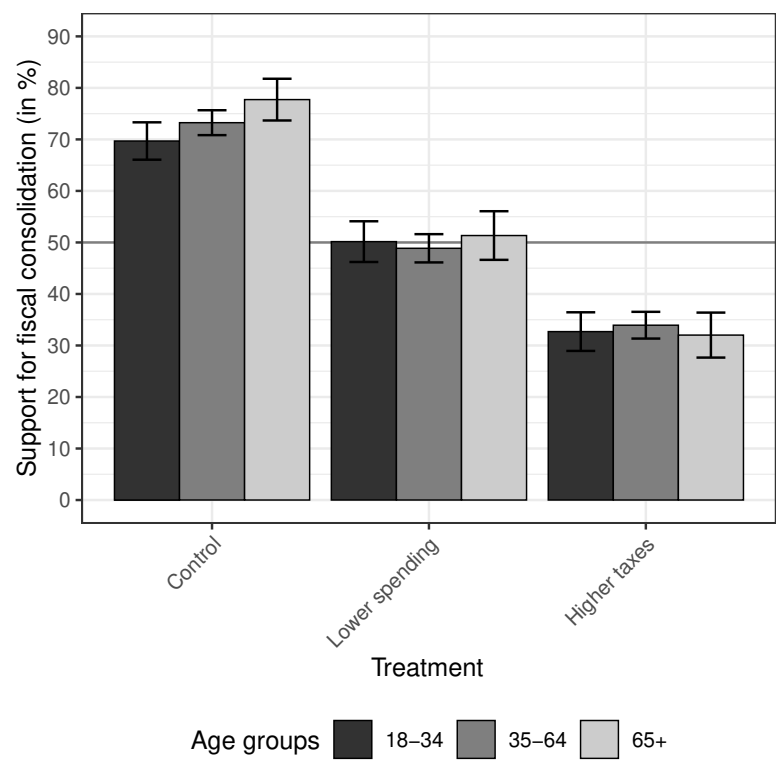

Figure A.5: Support for fiscal consolidation by trade-off and age group

Note: Share of respondents who support fiscal consolidation and 95 confidence intervals by trade-off and three age groups. 


\section{C.3 OLS regression analysis for split-sample experiment}

Table A.7: Average treatment effects on support for lower government debt (OLS regressions corresponding to Figure 1 in the main text)

\begin{tabular}{|c|c|c|c|}
\hline & \multicolumn{3}{|c|}{ Support for lower debt } \\
\hline & $\begin{array}{c}\text { No covariates } \\
(1)\end{array}$ & $\begin{array}{c}\text { Covariates } \\
(2)\end{array}$ & $\begin{array}{c}\text { Covariates }+ \text { country-FE } \\
(3)\end{array}$ \\
\hline \multicolumn{4}{|l|}{ Treatment (ref: control group) } \\
\hline Lower Spending & $\begin{array}{c}-1.58^{* * *} \\
(0.10)\end{array}$ & $\begin{array}{c}-1.55^{* * *} \\
(0.12)\end{array}$ & $\begin{array}{c}-1.56^{* * *} \\
(0.12)\end{array}$ \\
\hline Higher taxes & $\begin{array}{c}-2.63^{* * *} \\
(0.10)\end{array}$ & $\begin{array}{c}-2.59^{* * *} \\
(0.12)\end{array}$ & $\begin{array}{c}-2.60^{* * *} \\
(0.12)\end{array}$ \\
\hline Age & & $\begin{array}{c}-0.001 \\
(0.004)\end{array}$ & $\begin{array}{c}-0.002 \\
(0.004)\end{array}$ \\
\hline Female & & $\begin{array}{c}-0.30^{* *} \\
(0.10)\end{array}$ & $\begin{array}{c}-0.30^{* *} \\
(0.10)\end{array}$ \\
\hline Married & & $\begin{array}{c}0.003 \\
(0.11)\end{array}$ & $\begin{array}{c}0.01 \\
(0.11)\end{array}$ \\
\hline Children & & $\begin{array}{c}0.19 \\
(0.11)\end{array}$ & $\begin{array}{c}0.16 \\
(0.11)\end{array}$ \\
\hline \multicolumn{4}{|c|}{ Education (ref: primary/lower secondary) } \\
\hline Secondary & & $\begin{array}{c}-0.12 \\
(0.16)\end{array}$ & $\begin{array}{c}-0.20 \\
(0.16)\end{array}$ \\
\hline . Tertiary & & $\begin{array}{c}-0.20 \\
(0.17)\end{array}$ & $\begin{array}{c}-0.29 \\
(0.18)\end{array}$ \\
\hline \multicolumn{4}{|l|}{ Class (ref: Working Class) } \\
\hline Employer & & $\begin{array}{c}-0.12 \\
(0.17)\end{array}$ & $\begin{array}{c}-0.16 \\
(0.17)\end{array}$ \\
\hline Middle Class & & $\begin{array}{c}0.12 \\
(0.14)\end{array}$ & $\begin{array}{c}0.09 \\
(0.14)\end{array}$ \\
\hline Routine Worker & & $\begin{array}{c}0.13 \\
(0.21)\end{array}$ & $\begin{array}{c}0.11 \\
(0.21)\end{array}$ \\
\hline Income & & $\begin{array}{c}0.01 \\
(0.02)\end{array}$ & $\begin{array}{c}0.02 \\
(0.02)\end{array}$ \\
\hline Unemployed & & $\begin{array}{c}0.19 \\
(0.21)\end{array}$ & $\begin{array}{c}0.21 \\
(0.21)\end{array}$ \\
\hline Retired & & $\begin{array}{c}0.04 \\
(0.16)\end{array}$ & $\begin{array}{c}0.07 \\
(0.16)\end{array}$ \\
\hline Union membership & & $\begin{array}{r}-0.23^{*} \\
(0.11)\end{array}$ & $\begin{array}{r}-0.24^{*} \\
(0.11)\end{array}$ \\
\hline \multicolumn{4}{|l|}{ Partisanship (ref: Center Left) } \\
\hline Far left & & $\begin{array}{c}0.10 \\
(0.15)\end{array}$ & $\begin{array}{c}0.12 \\
(0.16)\end{array}$ \\
\hline . Center Right & & $\begin{array}{l}0.58^{* * *} \\
(0.13)\end{array}$ & $\begin{array}{l}0.64^{* * *} \\
(0.13)\end{array}$ \\
\hline . Far right & & $\begin{array}{c}0.28 \\
(0.20)\end{array}$ & $\begin{array}{c}0.22 \\
(0.20)\end{array}$ \\
\hline Other party & & $\begin{array}{c}0.06 \\
(0.24)\end{array}$ & $\begin{array}{c}0.20 \\
(0.24)\end{array}$ \\
\hline . Abstention & & $\begin{array}{c}0.23 \\
(0.16)\end{array}$ & $\begin{array}{c}0.26 \\
(0.17)\end{array}$ \\
\hline Country (ref: Germany). Spain & & & $\begin{array}{c}-0.04 \\
(0.14)\end{array}$ \\
\hline . Italy & & & $\begin{array}{c}0.40^{* *} \\
(0.15)\end{array}$ \\
\hline . UK & & & $\begin{array}{c}0.30^{*} \\
(0.14)\end{array}$ \\
\hline Constant & $\begin{array}{l}7.20^{* * *} \\
(0.07) \\
\end{array}$ & $\begin{array}{l}7.11^{* * *} \\
(0.31) \\
\end{array}$ & $\begin{array}{l}7.03^{* * *} \\
(0.32) \\
\end{array}$ \\
\hline Country fixed effects & No & No & Yes \\
\hline Observations & 3,607 & 2,768 & 2,768 \\
\hline $\mathrm{R}^{2}$ & 0.16 & 0.16 & 0.17 \\
\hline Adjusted $\mathrm{R}^{2}$ & 0.16 & 0.16 & 0.16 \\
\hline Residual Std. Error & 2.51 & 2.52 & 2.51 \\
\hline F Statistic & $333.69^{* * *}$ & $26.76^{* * *}$ & $23.95^{* * *}$ \\
\hline
\end{tabular}


Table A.8: The correlates of support for lower government debt (OLS regressions)

\begin{tabular}{|c|c|c|c|}
\hline & \multicolumn{3}{|c|}{ Support for lower debt } \\
\hline & $\begin{array}{l}\text { Control } \\
(1)\end{array}$ & $\begin{array}{l}\text { Lower spending } \\
\text { (2) }\end{array}$ & $\begin{array}{c}\text { Higher taxes } \\
(3)\end{array}$ \\
\hline Age & $\begin{array}{c}-0.003 \\
(0.01)\end{array}$ & $\begin{array}{c}-0.002 \\
(0.01)\end{array}$ & $\begin{array}{l}0.0002 \\
(0.01)\end{array}$ \\
\hline Female & $\begin{array}{c}-0.07 \\
(0.16)\end{array}$ & $\begin{array}{c}-0.33 \\
(0.18)\end{array}$ & $\begin{array}{c}-0.48^{* *} \\
(0.17)\end{array}$ \\
\hline Married & $\begin{array}{c}-0.02 \\
(0.18)\end{array}$ & $\begin{array}{c}0.21 \\
(0.20)\end{array}$ & $\begin{array}{c}-0.17 \\
(0.20)\end{array}$ \\
\hline Children & $\begin{array}{c}0.30 \\
(0.18)\end{array}$ & $\begin{array}{l}0.47^{*} \\
(0.20)\end{array}$ & $\begin{array}{c}-0.26 \\
(0.20)\end{array}$ \\
\hline \multicolumn{4}{|c|}{ Education (ref: primary/lower secondary) } \\
\hline Secondary & $\begin{array}{r}-0.56^{*} \\
(0.27)\end{array}$ & $\begin{array}{c}-0.16 \\
(0.30)\end{array}$ & $\begin{array}{c}-0.01 \\
(0.28)\end{array}$ \\
\hline Tertiary & $\begin{array}{r}-0.61^{*} \\
(0.29)\end{array}$ & $\begin{array}{c}-0.45 \\
(0.33)\end{array}$ & $\begin{array}{c}0.04 \\
(0.31)\end{array}$ \\
\hline \multicolumn{4}{|l|}{ Class (ref: Working Class) } \\
\hline Employer & $\begin{array}{c}-0.37 \\
(0.28)\end{array}$ & $\begin{array}{c}0.003 \\
(0.32)\end{array}$ & $\begin{array}{c}-0.003 \\
(0.31)\end{array}$ \\
\hline Middle Class & $\begin{array}{c}-0.31 \\
(0.23)\end{array}$ & $\begin{array}{c}0.23 \\
(0.27)\end{array}$ & $\begin{array}{c}0.42 \\
(0.25)\end{array}$ \\
\hline Routine Worker & $\begin{array}{c}0.25 \\
(0.34)\end{array}$ & $\begin{array}{c}0.17 \\
(0.38)\end{array}$ & $\begin{array}{c}0.06 \\
(0.35)\end{array}$ \\
\hline Income & $\begin{array}{l}0.06 \\
(0.03)\end{array}$ & $\begin{array}{c}-0.003 \\
(0.04)\end{array}$ & $\begin{array}{c}0.01 \\
(0.04)\end{array}$ \\
\hline Unemployed & $\begin{array}{l}0.76^{*} \\
(0.34)\end{array}$ & $\begin{array}{c}0.03 \\
(0.40)\end{array}$ & $\begin{array}{c}-0.04 \\
(0.37)\end{array}$ \\
\hline Retired & $\begin{array}{c}0.35 \\
(0.25)\end{array}$ & $\begin{array}{c}-0.16 \\
(0.28)\end{array}$ & $\begin{array}{c}0.01 \\
(0.28)\end{array}$ \\
\hline Union membership & $\begin{array}{r}-0.37^{*} \\
(0.18)\end{array}$ & $\begin{array}{c}-0.24 \\
(0.20)\end{array}$ & $\begin{array}{c}-0.05 \\
(0.19)\end{array}$ \\
\hline \multicolumn{4}{|l|}{ Partisanship (ref: Center Left) } \\
\hline Far left & $\begin{array}{c}0.06 \\
(0.25)\end{array}$ & $\begin{array}{c}0.05 \\
(0.30)\end{array}$ & $\begin{array}{c}0.21 \\
(0.28)\end{array}$ \\
\hline Center Right & $\begin{array}{l}0.47^{*} \\
(0.21)\end{array}$ & $\begin{array}{l}0.72^{* *} \\
(0.23)\end{array}$ & $\begin{array}{c}0.68^{* *} \\
(0.23)\end{array}$ \\
\hline Far right & $\begin{array}{c}0.23 \\
(0.30)\end{array}$ & $\begin{array}{c}0.47 \\
(0.37)\end{array}$ & $\begin{array}{c}-0.08 \\
(0.37)\end{array}$ \\
\hline Other party & $\begin{array}{l}0.45 \\
(0.40)\end{array}$ & $\begin{array}{c}0.01 \\
(0.40)\end{array}$ & $\begin{array}{c}0.06 \\
(0.47)\end{array}$ \\
\hline Abstention & $\begin{array}{c}0.25 \\
(0.26)\end{array}$ & $\begin{array}{c}0.54 \\
(0.29)\end{array}$ & $\begin{array}{c}-0.12 \\
(0.30)\end{array}$ \\
\hline Country (ref: Germany). Spain & $\begin{array}{c}0.55^{*} \\
(0.22)\end{array}$ & $\begin{array}{c}-0.79^{* *} \\
(0.25)\end{array}$ & $\begin{array}{c}0.13 \\
(0.25)\end{array}$ \\
\hline Italy & $\begin{array}{l}1.01^{* * *} \\
(0.23)\end{array}$ & $\begin{array}{c}-0.05 \\
(0.27)\end{array}$ & $\begin{array}{c}0.21 \\
(0.27)\end{array}$ \\
\hline UK & $\begin{array}{c}0.16 \\
(0.23)\end{array}$ & $\begin{array}{c}0.04 \\
(0.26)\end{array}$ & $\begin{array}{l}0.65^{* *} \\
(0.25)\end{array}$ \\
\hline Constant & $\begin{array}{l}6.97^{* * *} \\
(0.49) \\
\end{array}$ & $\begin{array}{l}5.65^{* * *} \\
(0.56) \\
\end{array}$ & $\begin{array}{l}4.25^{* * *} \\
(0.55) \\
\end{array}$ \\
\hline Country fixed effects & Yes & Yes & Yes \\
\hline Observations & 915 & 925 & 928 \\
\hline $\mathrm{R}^{2}$ & 0.06 & 0.05 & 0.04 \\
\hline Adjusted $\mathrm{R}^{2}$ & 0.04 & 0.03 & 0.02 \\
\hline Residual Std. Error & 2.27 & 2.62 & 2.57 \\
\hline F Statistic & $2.75^{* * *}$ & $2.27^{* * *}$ & $2.00^{* *}$ \\
\hline
\end{tabular}


Table A.9: The correlates of support for lower government debt (OLS regressions with additional control variables)

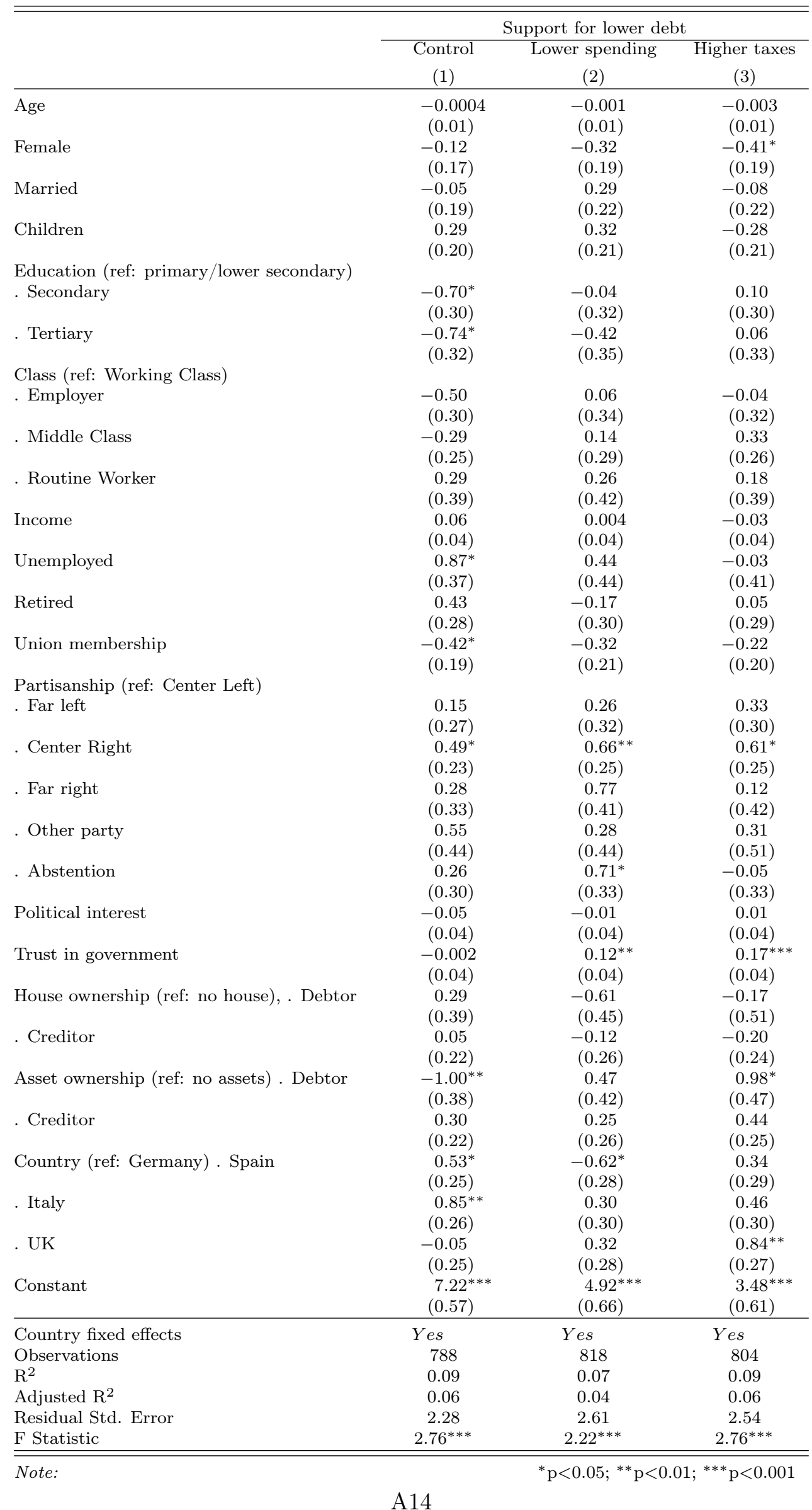




\section{Instructions for the conjoint survey experiment}

The full instructions for the conjoint tasks are shown below. First, respondents were presented the following introduction to the experiment.

Please take your time and read the information below very carefully. It contains the instructions for the next part of the survey.

Every year the [COUNTRY] government collects taxes and spends money in a variety of different areas. A large share of taxes are paid by citizens like you and they are used to pay for government spending on education or pensions. We are interested in what you think about how your government should change its budget.

We will now show you several proposals for possible changes to the government's budget. We will always show you two possible proposals in comparison. For each comparison we would like to know which of the two proposals you prefer. You may like both proposals or neither. In any case, please choose the proposal that you like the most. In total, we will show you five comparisons.

The possible proposals only include changes with regard to a few selected types of government spending and taxation. Please assume that spending in all other areas as well as all other taxes do not change.

People have different opinions about this issue and there are no right or wrong answers. Please always take your time when reading the proposals.

This introduction was followed by a screen with two proposals for a budgetary change, as shown below in Figure A.6. In this way, respondents are asked five times to choose (i) between two packages ("choice" variable) and (ii) to indicate how likely they are to support each of the proposals ("ranking" variable). 
Please carefully review the options detailed below, then please answer the questions.

Which of these proposals do you prefer?

\begin{tabular}{|c|c|c|}
\hline & Proposal 1 & Proposal 2 \\
\hline Income tax (for all citizens) & Decrease & No change \\
\hline Tax on high incomes & Increase & No change \\
\hline Value added tax (VAT) & Decrease & Increase \\
\hline Government debt & Increase & Decrease \\
\hline Old-age pensions & Decrease spending & Decrease spending \\
\hline Education & Increase spending & Increase spending \\
\hline
\end{tabular}

\section{Proposal 1}

\section{Proposal 2}

How would you rate proposal 1 on a scale from 0 to 10 , where 0 indicates that the government should definitely not adopt the proposal and 10 indicates that the government should definitely adopt it?

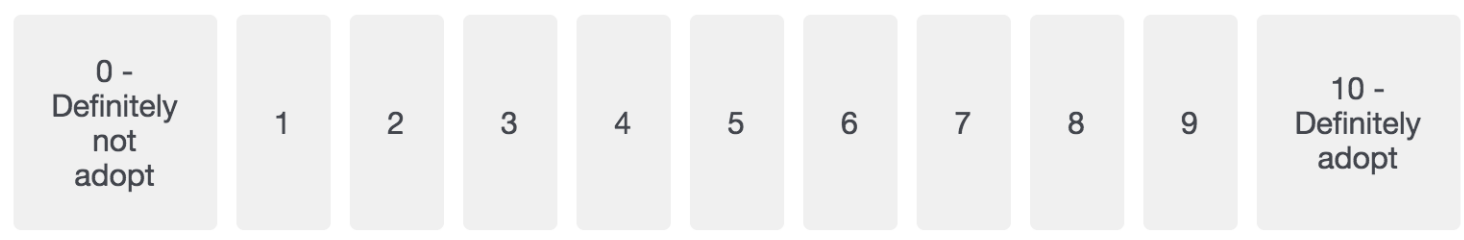

How would you rate proposal 2?

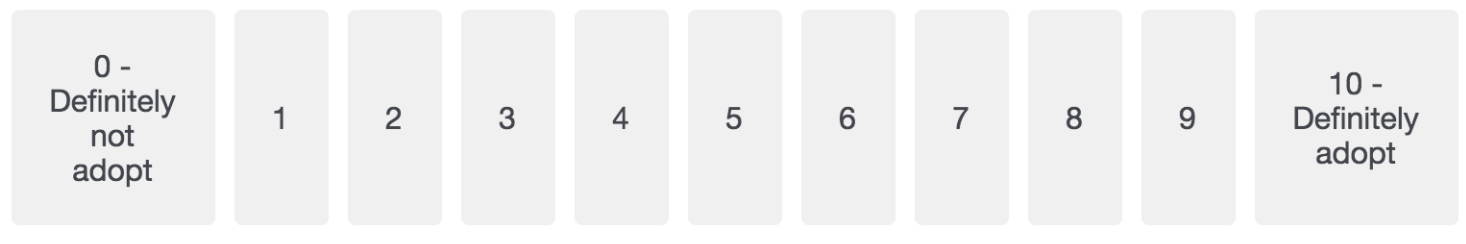

Figure A.6: Screenshot of a conjoint task presented to respondents 


\section{E Explanation of ridge regression to analyze the conjoint exper- iment}

We propose ridge regression as a novel method to analyse conjoint survey experiments with dependencies. In our design, the values that each attribute can take are linearly dependent on the other attributes to ensure that the budget is balanced. Therefore, there is explicit confounding between the features of the fiscal packages, due to the restrictions to the randomization protocol that we introduced. We included these restrictions to increase external validity, as recommended by Hainmueller et al. (2014, p. 26). They argued that "researchers should employ restrictions and exclude attribute combinations whenever they are deemed so unrealistic that a counterfactual would essentially be meaningless." We took this recommendation to the extreme because the budget constraint of the public budget is binding: changing the government's expenditure or revenue on one dimension necessarily has consequences for another dimension. This poses difficulties for traditional regression analysis, but it ensures external validity.

To see this, imagine the alternative: We could have introduced combinations that are unrealistic to break the super-collinearity that exists in reality. This would have allowed us isolate the effect of each attribute independently of other attributes, but it poses a threat to external validity. Respondents would have probably most preferred atypical profiles, which increase government spending, decrease taxation, and cut government debt all at the same time. Given our interest in citizens' priorities in the face of hard budgetary tade-offs, this would not have been satisfactory. As Bansak et al. (2020, p. 24-25) argue, "the AMCE averages the effect of an attribute over two different distributions: the randomization distribution of the other attributes and the distribution of respondents." The AMCEs of a fully randomized design, therefore, are not of interest to us. We only wanted to make inferences about realistic budgetary combinations, i.e., those that are fully balanced.

The resulting experimental design necessitates a modelling approach which accounts for the design-based super collinearity. One common solution to enable OLS standard regression analysis in instances of super collinearity is to drop one of the correlated variable. This strategy usually works well, but it is not useful in our case because it defeats the point of the design. We are interested in the support for a fiscal package as a function of all of its individual attributes. Moreover, dropping one attribute from the analysis may lead to specification bias. 
We, therefore, propose to use regularization to analyse the results from conjoint experiments, which are perfectly multicollinear. Specifically, we use ridge regression, which is a common regularization method that adds a penalty term to the common OLS regression. Hoerl (1962) and Hoerl and Kennard (1970) suggested to use a ridge regression as an ad-hoc fix to address instances of high multicollineary, including instances of design-based collinearity. It allows one to estimate coefficients for all independent variables in the model even in the presence of super collinearity, and consequently, the method is also used in fields such as genetics where a set of related genetic predictors may jointly cause certain diseases.

To see how ridge regression works, recall that OLS regression attempts to minimize the sum of errors squared, as shown in the equation below:

$$
\sum_{i=1}^{M}\left(y_{i}-\hat{y}_{i}\right)^{2}=\sum_{i=0}^{M}\left(y_{i}-\sum_{j=0}^{p} w_{j} w_{i j}\right)^{2}
$$

Ridge regression adds the following term to this model:

$$
+\lambda \sum_{j=0}^{p} w_{j}^{0}
$$

This term is referred to as the ridge penalty and $\lambda$ is the penalty parameter. If $\lambda$ is zero, then ridge regression is essentially an OLS regression. However, if $\lambda$ is above zero, then it adds a constraint to the coefficient. This constraint minimizes the coefficients (which is called shrinkage), which results in a lower variance and a lower error value. Consequently, ridge regression is a way to decrease the complexity of a model without reducing the number of variables. It is a solution to a constrained estimation problem.

Importantly, the ridge penalty shrinks large regression coefficients of correlated predictors and reduces overfitting. Contrary to Lasso regression, an alternative regularization method, ridge regression does not shrink coefficients to zero ${ }^{16}$ It includes all independent variables in the data and is thus a good way to analyze results from conjoint survey experiments with a large number of restrictions. The "shrinkage estimators" performs better than OLS when the data matrix is

\footnotetext{
${ }^{16}$ Lasso regression is thus especially useful for model selection.
} 
relatively sparse, but it introduces a bias in the estimates due to the ridge penalty. Given that the bias introduced by the ridge penalty is systematic, it still allows us to make inferences about respondents' priorities in our case. Our empirical strategy thus provides a modelling strategy for the underlying utility function behind respondents' choice of fiscal packages, while maintaining predictive performance and interpretability.

We use the $\mathrm{R}$ package glmnet to find the best value of $\lambda$ through cross-validation. We then proceed by using this optimal $\lambda$ to estimate the regression coefficients (also referred to as AMCEs) and marginal means. Ridge regression does not provide standard errors for coefficients, but we rely on non-parametric boot-strapping to calculate standard errors and confidence intervals. To this end, we wrote a $\mathrm{R}$ function which calculates the same ridge regression 1000 times with a random sample of our observations and calculates standard errors based on the uncertainty of the results. This is a popular method for parametric inference, and it allows us to assign a measure of accuracy to the coefficients obtained from the ridge regression. 


\section{F Additional results from the conjoint experiment}

\section{F.1 Marginal mean plots from the conjoint experiment}

To test the robustness of our findings, we further calculated the marginal means for different groups in our conjoint survey experiments (following the recommendations of (Leeper et al., 2020). First, we calculated the marginal means for the overall sample to map the levels of favorability towards the multidimensional fiscal package across the various attribute levels (Figure A.7).

Second, we calculated marginal means for subgroups to test for heterogeneous effects by occupation, party family, ideology (left-right self placement), electoral participation (voting vs. abstention), asset ownership, different income groups (top 10 vs. bottom 90), employment activity, gender, and age (not shown). The results indicate that there are only few heterogeneous effects which are all very small.

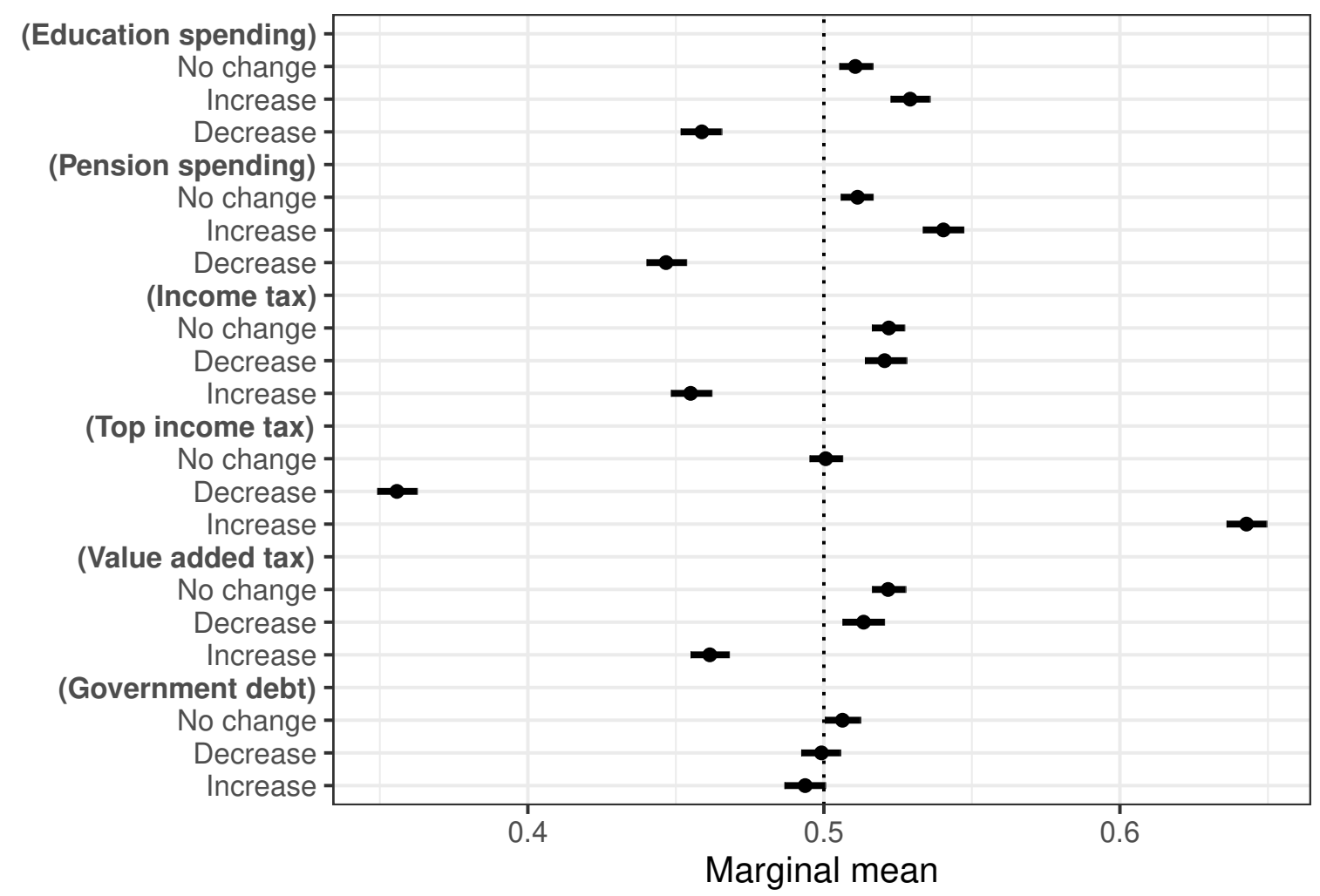

Figure A.7: Estimated marginal means from conjoint survey experiment, pooled.

Note: The figure shows the the conditional marginal means for all attribute levels. The marginal means measure how favorable respondents are to a given feature of the reform package. 


\section{F.2 Distribution plots based on rating variable}
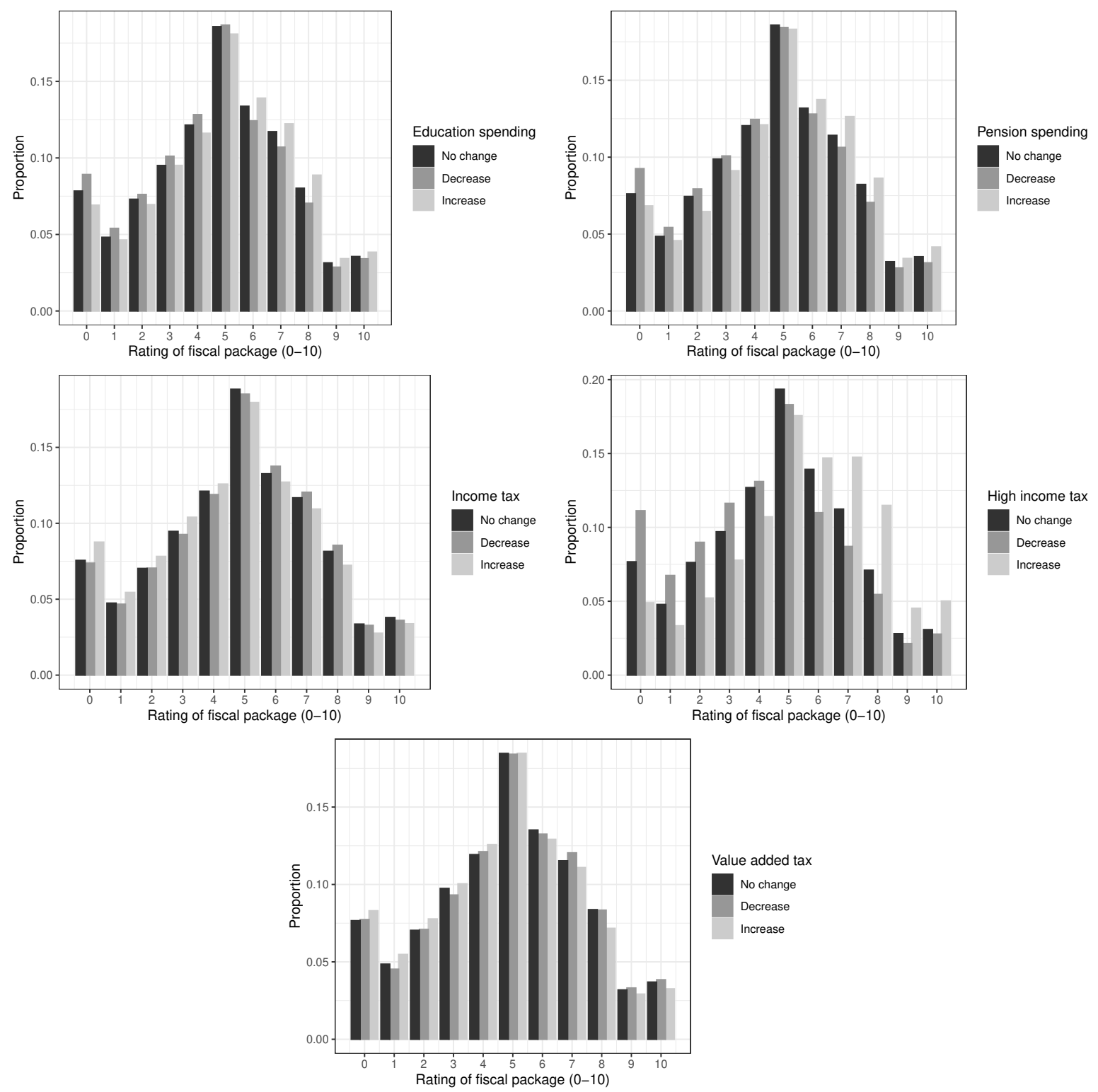

Figure A.8: Distribution of the ratings of all fiscal packages by changes of all attributes other than debt

Note: The figure shows the distribution of ratings of all conjoint packages by the attribute level for all attributes other than debt (e.g., no change, increase government debt, decrease government debt). The dependent variable asked respondents to rate each fiscal package on an 11-point Likert scale from 0 to 10. 


\section{F.3 Conjoint analysis with the rating variable}

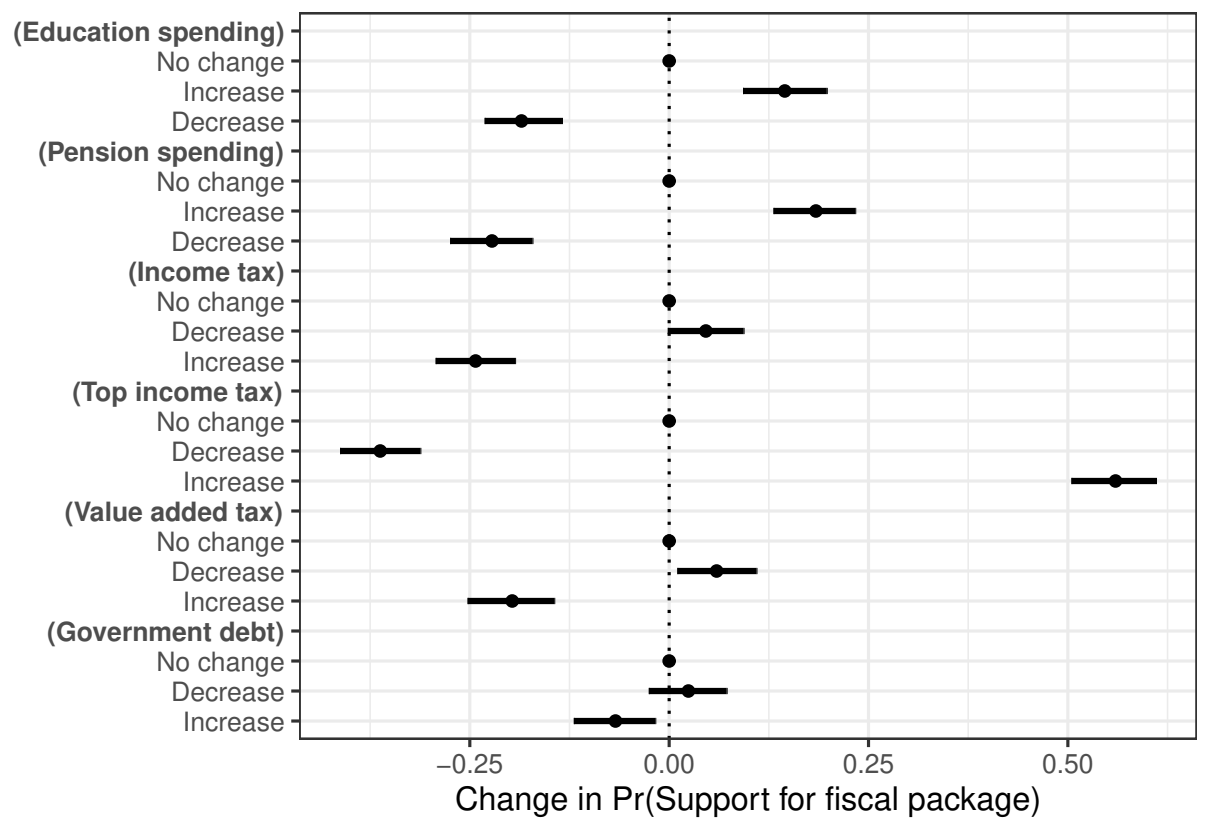

Figure A.9: AMCEs from conjoint survey experiment with rating variable, pooled.

Note: The figure shows the average marginal component effect (AMCE) of a change in the value of one of our six dimensions on the probability that the fiscal package is chosen by the respondent.

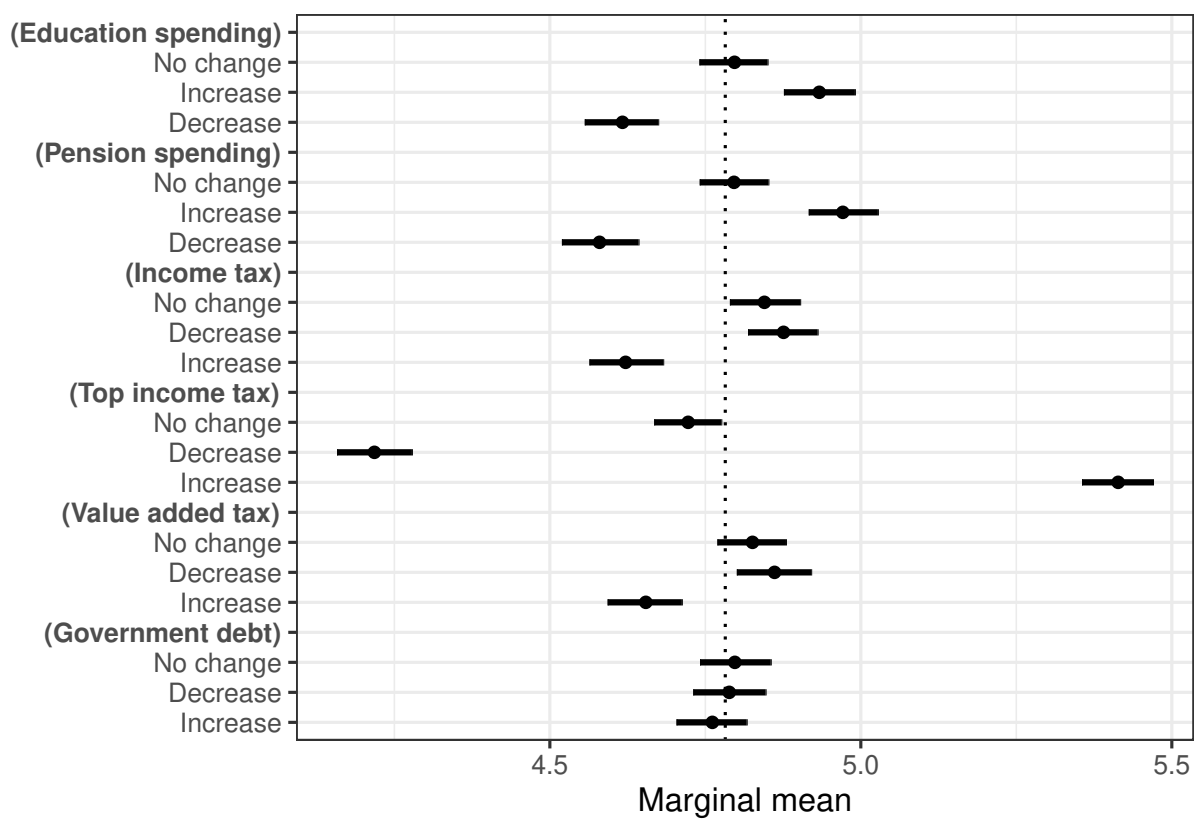

Figure A.10: Estimated marginal means from conjoint survey experiment with rating variable, pooled.

Note: The figure shows the the conditional marginal means for all attribute levels. The marginal means measure how favorable respondents are to a given feature of the reform package. 


\section{F.4 Tests for other heterogeneous treatment effects from the conjoint exper- iment}

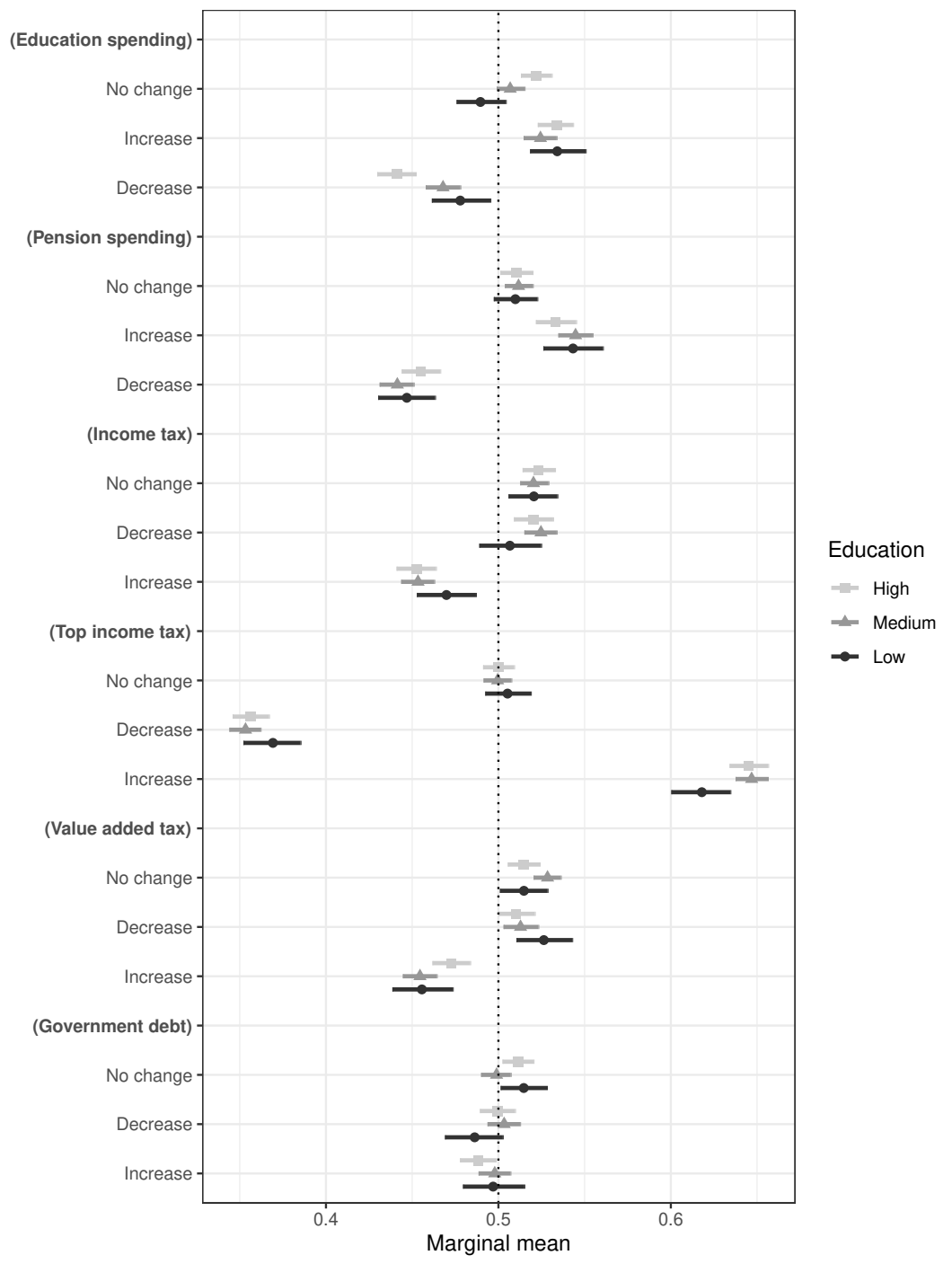

Figure A.11: Estimated marginal means from the conjoint survey experiment by education Note: The figure shows the conditional marginal means for all attribute levels by education. The marginal means measure how favorable respondents are to a given feature of the reform package. The figure distinguishes between three education groups (low, middle, high). 


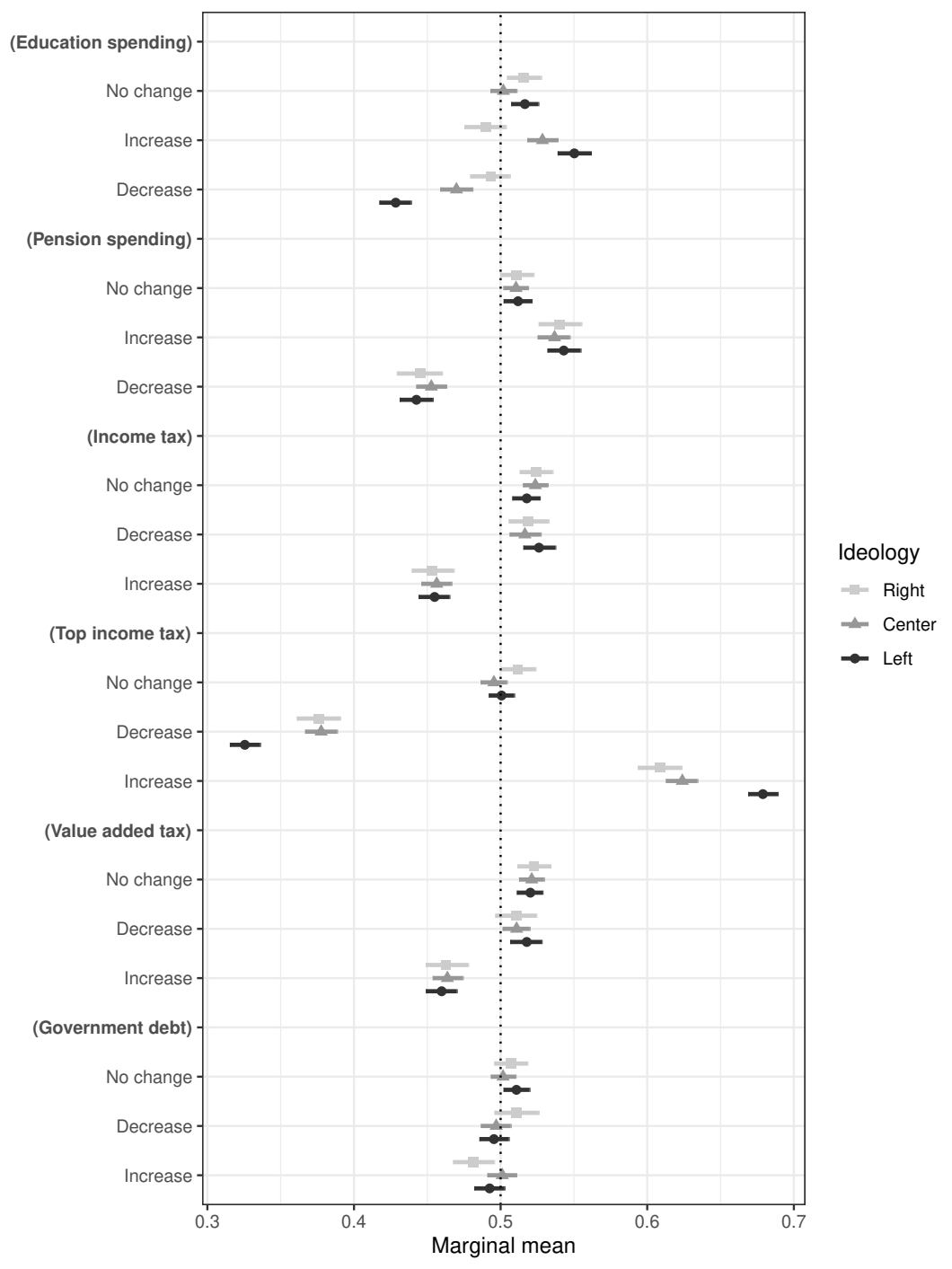

Figure A.12: Estimated marginal means from the conjoint survey experiment by ideology Note: The figure shows the conditional marginal means for all attribute levels by ideology. The marginal means measure how favorable respondents are to a given feature of the reform package. The figure distinguishes between three ideological groups based on respondents' left-right selfplacement. 


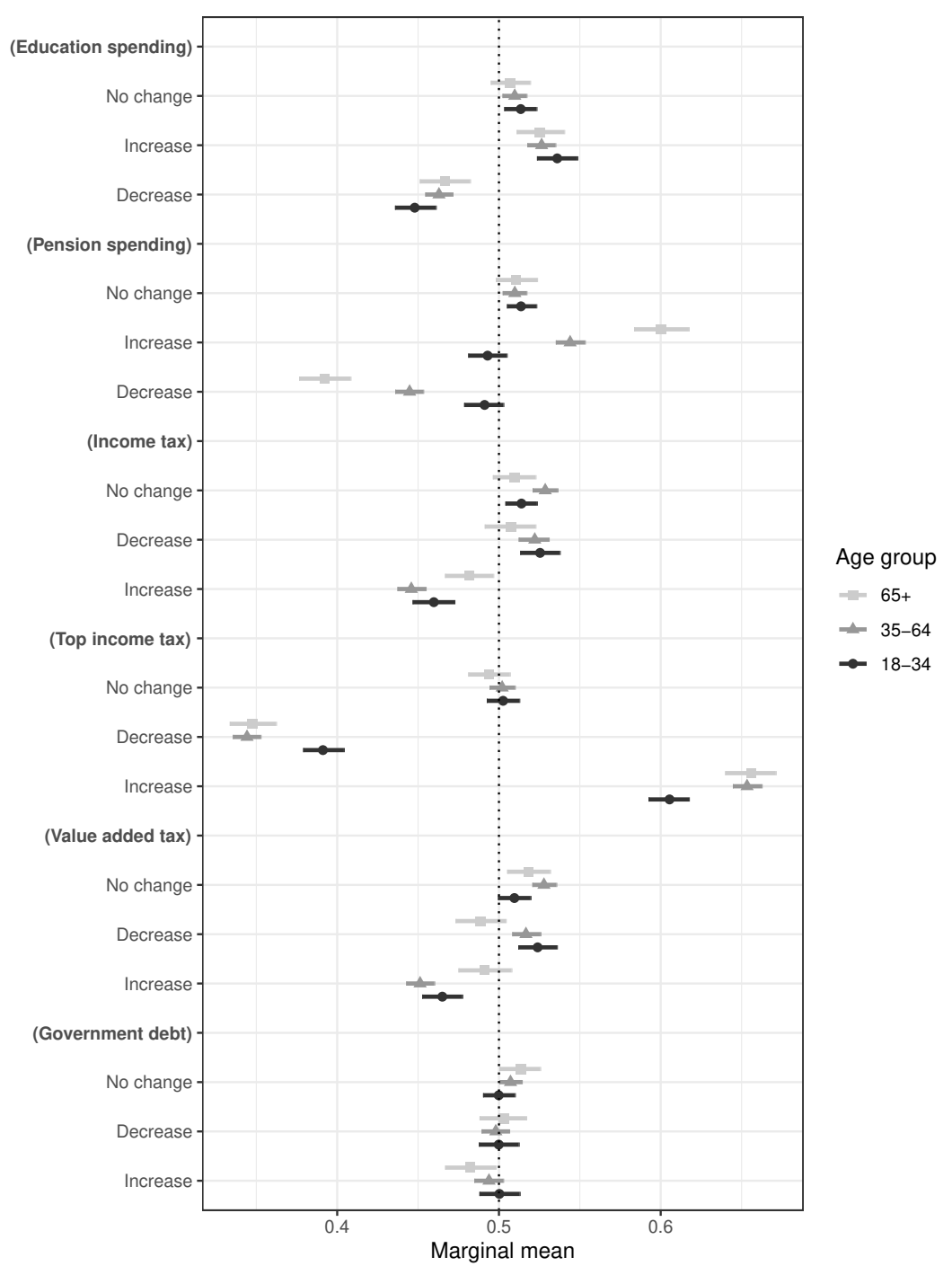

Figure A.13: Estimated marginal means from the conjoint survey experiment by age Note: The figure shows the conditional marginal means for all attribute levels by age. The marginal means measure how favorable respondents are to a given feature of the reform package. The figure distinguishes between three age groups. 


\section{G Analysis with entropy balancing}

We worked with the survey company Qualtrics to obtain an online sample that was representative of the population based on key indicators such as age and gender in each country. To test that there were no other biases in our sample that influence our results, however, we also used entropy balancing to create survey weights using the $\mathrm{R}$ package ebal. Based on margins from the population in each country, we created these weights based on age, gender, and education. We then replicated our analyses and the results are shown below. We also created weights based on income (not shown). Substantively, the results with the weighted analyses are not different from the results shown in the main text.

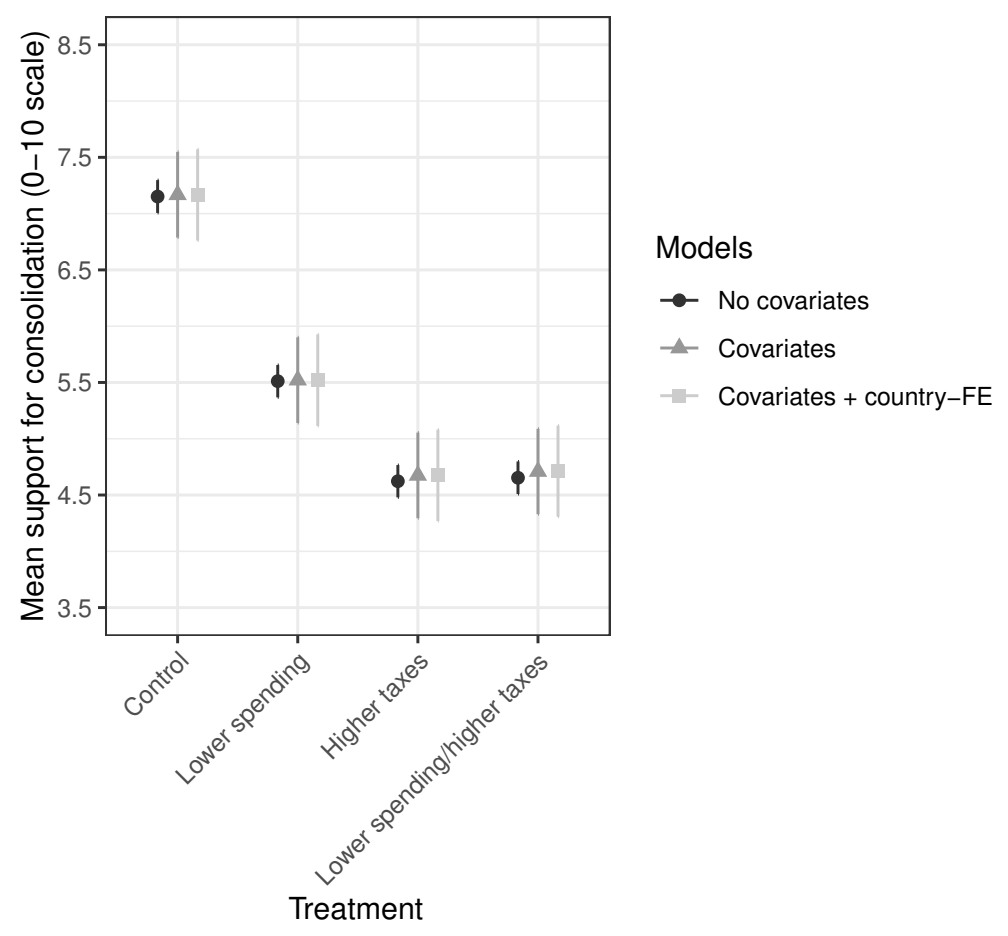

Figure A.14: Weighted average support for fiscal consolidation by treatment 

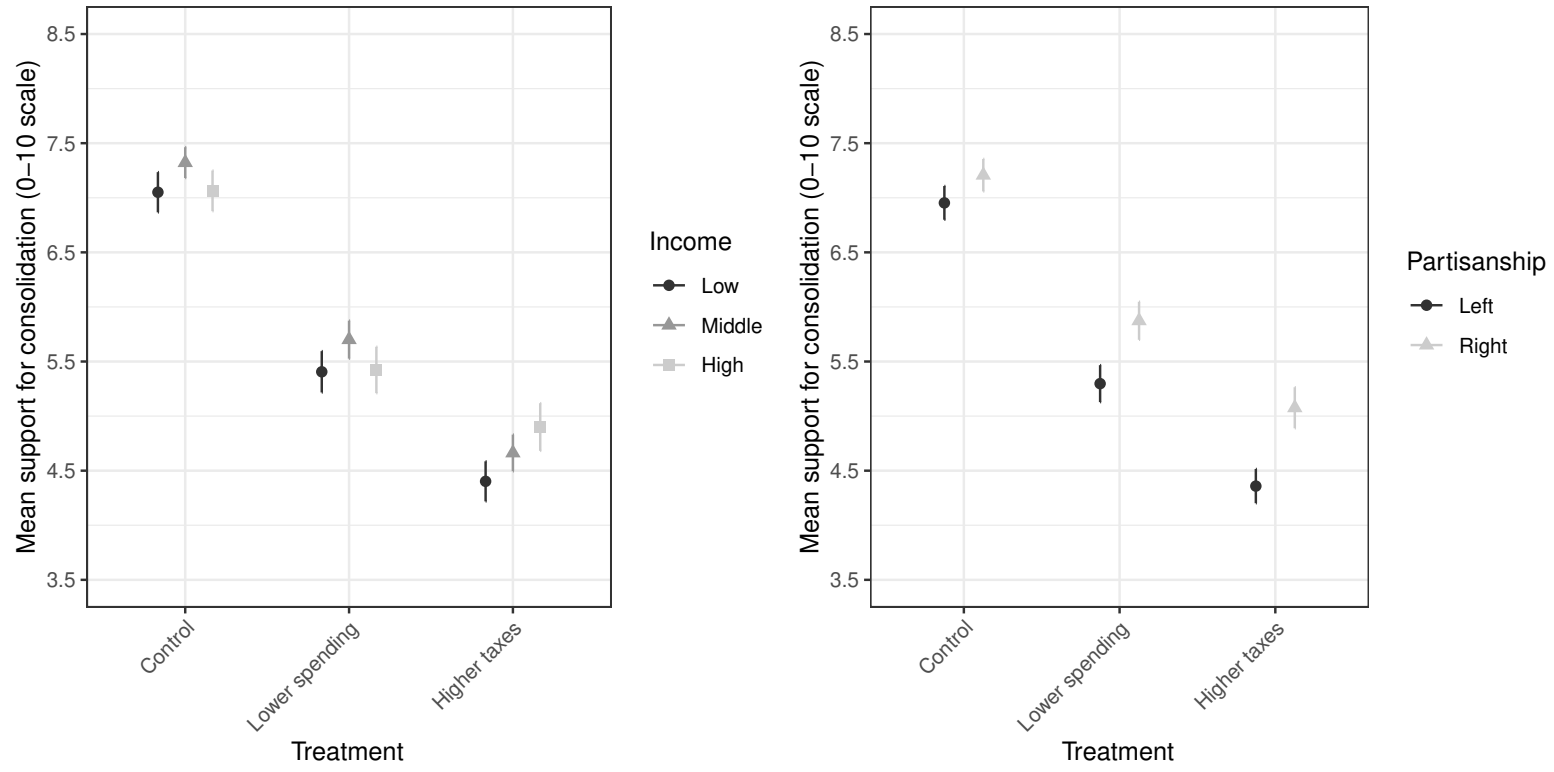

Figure A.15: Weighted average support for fiscal consolidation by trade-off and income/partisanship

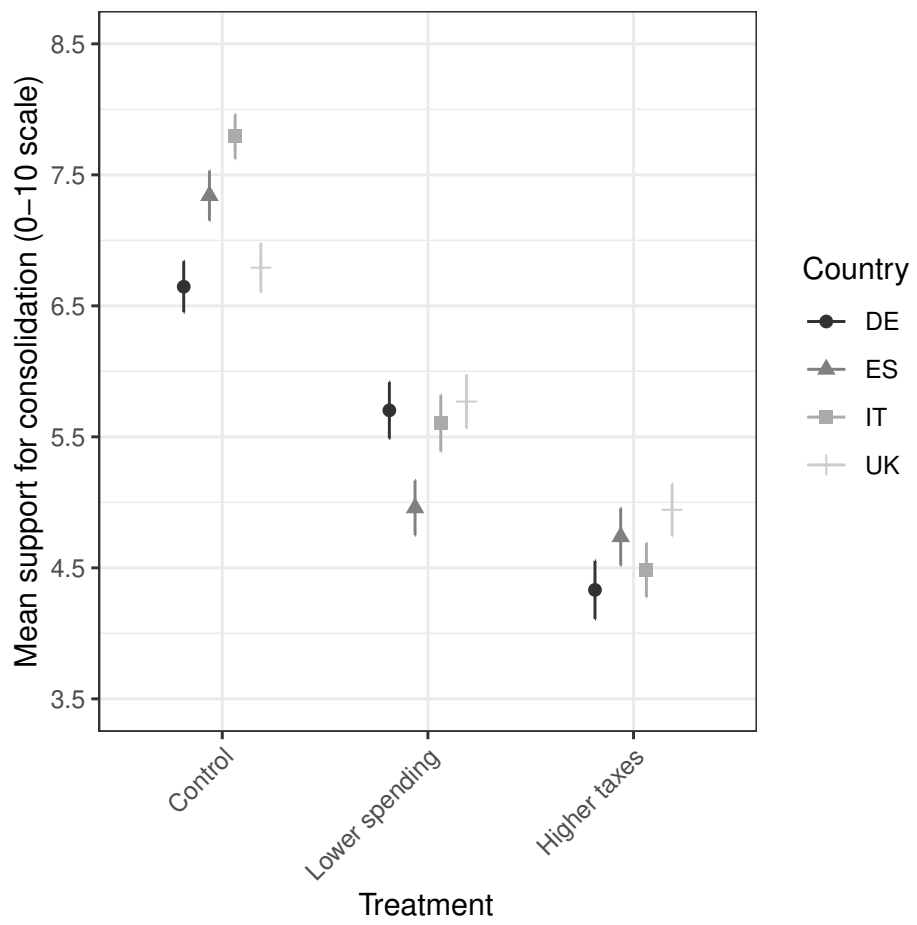

Figure A.16: Weighted average support for fiscal consolidation by trade-off and country 


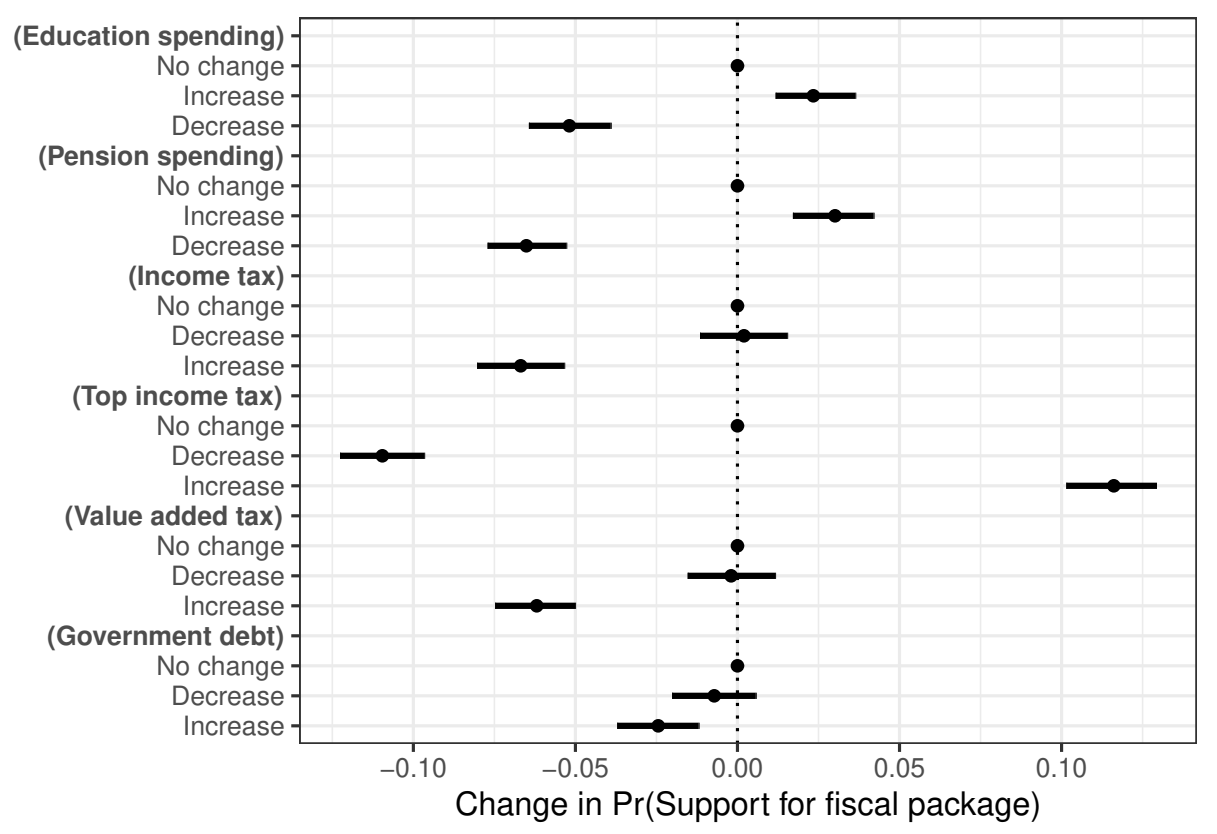

Figure A.17: Weighted AMCEs from conjoint survey experiment

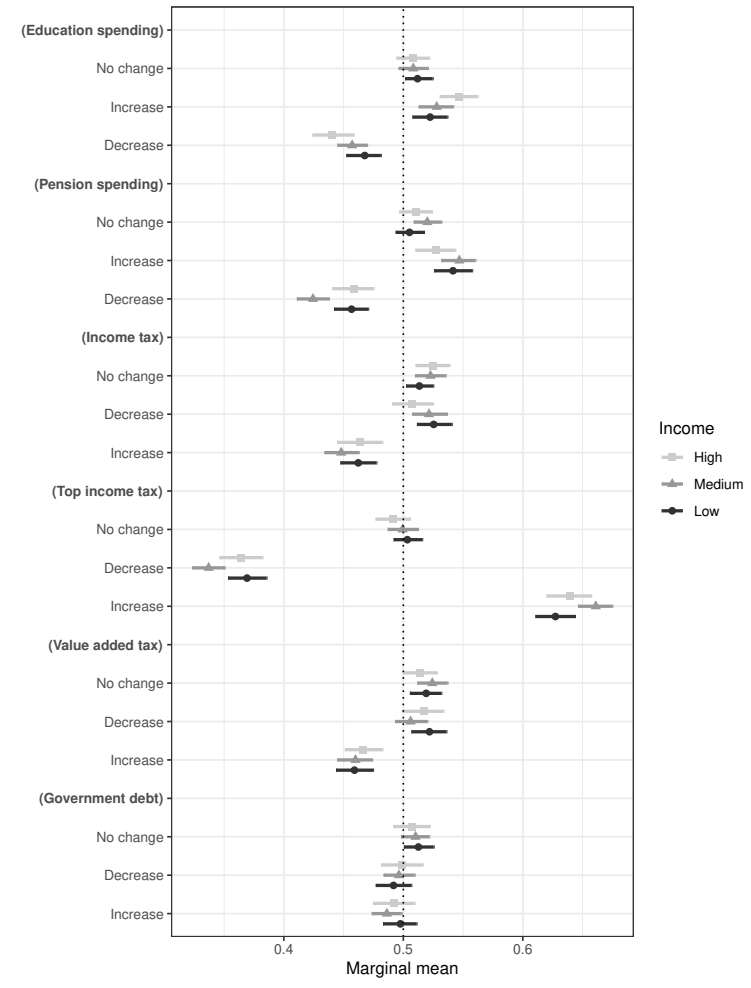

(a) By income groups

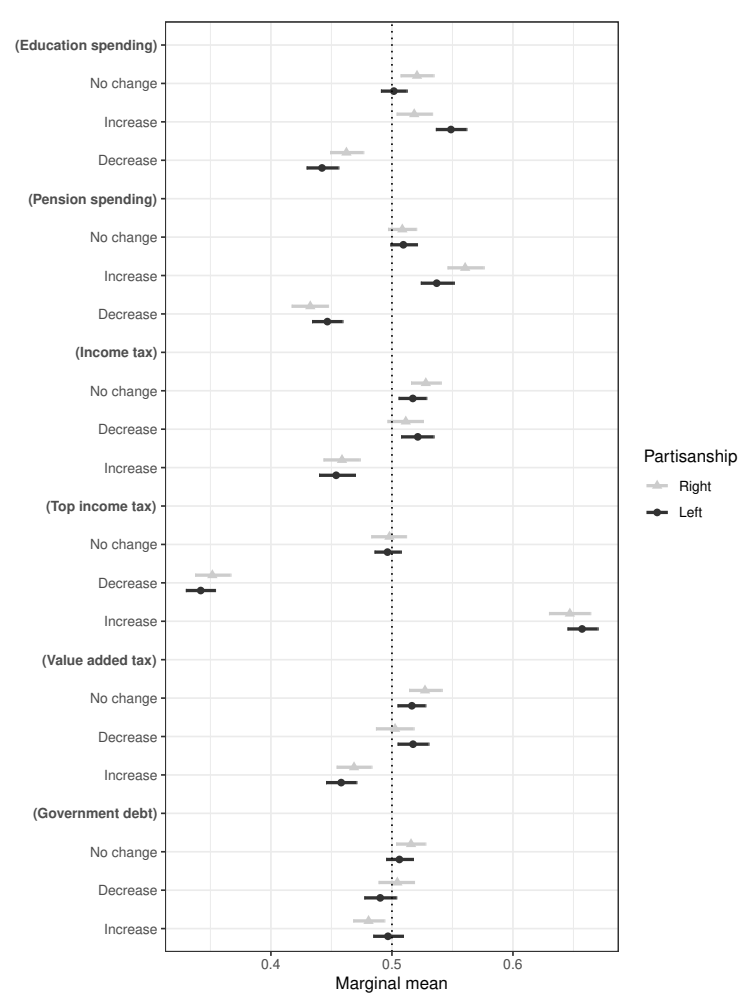

(b) By partisanship

Figure A.18: Weighted marginal means from conjoint survey experiment by income and party 


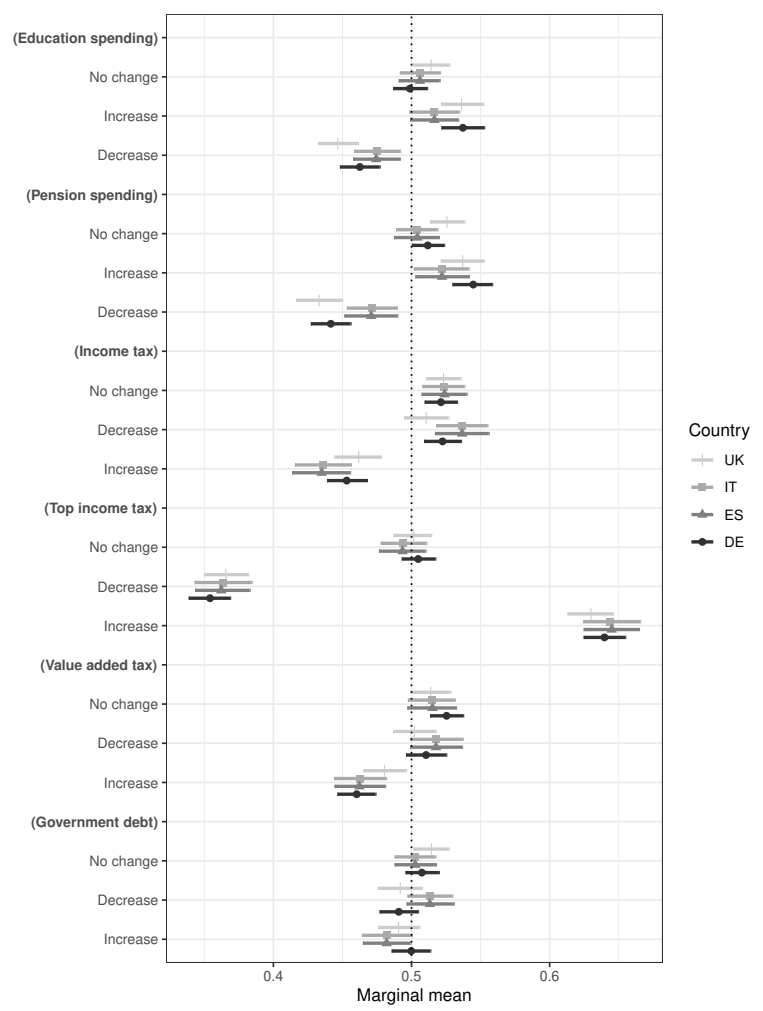

Figure A.19: Weighted marginal means from conjoint survey experiment by country 


\section{H Robustness tests for the conjoint survey experiment}

We used a series of tests to confirm that the results are robust. These robustness tests were designed to check that the common assumptions involved in conjoint analysis are satisfied and to probe potential concerns about the validity of the results. On the one hand, we conducted several diagnostic tests suggested by Hainmueller et al. (2014). First, conjoint analyses relies on the assumption that there are no carryover effects between the different rounds of conjoint tasks. To test whether this assumption holds, we estimated AMCEs separately for each of the five rounds of conjoint tasks.

Second, we checked whether there are profile order effects, i.e., whether the AMCEs depend on whether the attribute occurs in the first or second profile in a given task. To this end, we estimated AMCEs separately for all the observations where attribute levels occurred in the first and the second profile respectively.

Finally, note that we already addressed the concern about atypical profiles raised by Hainmueller et al. (2014) in the research design. Specifically, we included a large number of restrictions to prevent profiles that are unrealistic and would not occur in the real world. This allows us to analyze the priorities of respondents under the presence of strong and realistic trade-offs.

One the other hand, we also used further robustness tests, which are important due to the design of the survey. First, we checked whether respondents lost concentration throughout the survey by estimating all results based on the first two (out of five) conjoint comparisons only. Moreover, we included round or task fixed effects to take account of the fact that respondents might make different choices in later stages of the conjoint experiment, for example due to fatigue or lack of concentration.

Second, we assessed the relative time that respondents took to complete the conjoint tasks and we excluded those respondents that speed through the conjoint tasks, comparing the results with the overall sample. We also distinguished respondents by the time that they took overall for the survey and used subgroup analysis to test whether our results are robust across groups.

Third, the conjoint survey experiment described above was embedded in a survey, which included two different set of conjoint tasks. The order in which these conjoint experiments 
occurs in the survey was randomized. Still, we checked whether respondents are influenced in their evaluations of the conjoint profiles if they have already completed a different set of conjoint tasks beforehand. For this purpose, we split the sample and analyzed the results separately depending on whether the conjoint experiment occurred before or after the other conjoint experiment in the survey.

Fourth, there is also a possibility that the screen size might affect the way respondents evaluate the conjoint tasks. We therefore also separately analyzed responses from mobile versus non-mobile respondents and checked to what extent they differ. All of these robustness checks yielded similar results to the ones shown here. 


\section{References}

Bansak, K., J. Hainmueller, D. J. Hopkins, and T. Yamamoto (2020). Using conjoint experiments to analyze elections: The essential role of the average marginal component effect (amce). Social Science Research Network.

Hainmueller, J. (2012). Entropy balancing for causal effects: A multivariate reweighting method to produce balanced samples in observational studies. Political Analysis 20(1),25-46.

Hainmueller, J., D. J. Hopkins, and T. Yamamoto (2014). Causal inference in conjoint analysis: Understanding multidimensional choices via stated preference experiments. Political Analysis $22(1), 1-30$

Hoerl, A. E. (1962). Application of Ridge analysis to regression problems. Chemical Engineering Progress 58, 54-59.

Hoerl, A. E. and R. W. Kennard (1970). Ridge regression: Biased estimation for nonorthogonal problems. Technometrics 12(1), 55-67. 